Research Paper

\title{
SHAPING COMPACT CITIES FOR LIVEABILITY, AFFORDABILITY AND SUSTAINABILITY (L-A-S)
}

\section{A Comparative Assessment of TODs in Jakarta and Auckland}

Author 1 Felicia ATMADJA, University of Auckland; New Zealand

Author 2 Dushko BOGUNOVICH, University of Auckland; New Zealand

\begin{abstract}
Rapid urban population and territorial growth is becoming a general trend across the world, driving planning policies to promote a more compact city. As an alternative to sprawling patterns of urban development, the compact city emerges as a spatial form characterized by three key elements: densification, connectivity and accessibility. All three are articulated by transit-oriented development (TOD) strategies in today's urban context. TOD aims to encourage densification, mixed land uses, walkability and public transportation, as well as vertical housing typologies. There are now many examples around the world in which TOD has influenced the verticalization of the city, and we can expect further translations into other contexts. Auckland and Jakarta have too chosen the TOD strategy, incorporating vertical housing, to slow down the sprawl. But citizens are concerned about the quality of life in high-rise, higher density housing, as well as its price. We make a comparative assessment of TOD's ability to achieve liveability, sustainability and affordability in two cities - Jakarta and Auckland - while using Singapore as a benchmark for both. Two case studies have shown that some of the residents' complaints are justified. In the conclusion of the study we suggest improvements in planning and design strategies and produce further recommendations for an effective city transformation.
\end{abstract}

\section{Keywords}

TOD, Liveability, Affordability, Sustainability, Jakarta, Auckland

\section{Introduction}

\subsection{The Aim and Scope}

This paper is about the effectiveness of the well know urban planning and design strategy called 'Transit Oriented Development' (TOD). The 'effectiveness' in this case is defined as achieving the nowadays widely shared urban development goals of: (a) good city life commonly labelled as 'Liveability'; (b) acceptable housing costs - commonly labelled as 'affordability'; and (c) environmental responsibility - commonly referred to as 'sustainability'.

The paper aims to assess the achievements of comparable TODs in two rather different cities - Auckland, New Zealand, and Jakarta, Indonesia - to then draw useful conclusions, some of which may have international relevance. The conclusions are then reframed into recommendations that aspire to be of practical value to the city authorities, developers and 
planning professional in Auckland and Jakarta, as well as, hopefully, to other large cities in the world which operate with the 'compact city' model. This paper is accompanied with a presentation which summarises and illustrates the main points of the study.

\subsection{Compact City and TOD: A Brief History}

Historically, the compact city concept can be seen in medieval and ancient cities which were compact in size following a clear wall boundary surrounding the city. Following the middle ages and Renaissance, came the age of public transport in the Industrial Age, which, mainly in the form of tramway and railway, enabled a degree of urban expansion, but still with a rather compact urban fabric. After that, came the Automobile Age, and the compact city concept started to be used as a strategy to tackle rapid and expansive urbanisation in the late $20^{\text {th }}$ century. In the $1980 \mathrm{~s}$, the emergence of sustainable development promoted the concept of compact city as the most sustainable urban form, in order to ensure that cities, as they grow, become more efficient in their use of the natural environment (Jabareen, 2006; Newman and Kenworthy, 1999; OECD, 2012). As an alternative to sprawling city development, the compact city is a spatial form characterized by three key elements (OECD, 2012). The first is a dense and proximate development pattern which is usually achieved through intensification of development and activity in an urban area. The second is connectivity which involves public transport systems to facilitate mobility in urban areas. The third is accessibility, which suggests the mixed-use development integrating residential, commercial and business activities within walking distance.

There has however been criticism of the 'compact city' idea as well, mostly arguing that the environmental sustainability effects have been exaggerated (Neuman, 2005) and never properly proven (Asa, 2018). Other studies argued that the advent of climate change has changed the priorities, so that adaptation and resilience are now more important than mitigation and sustainability (Bogunovich, 2009). In this light, the lower, suburban densities have more advantages for survival than the higher densities in the heavily infrastructuredependent central city areas (Bogunovich, 2009 and 2012). Leaving these debates aside, the dominant position remains that excessive urban expansion is unwanted; that very large metropolitan areas must have strong public transit networks, and that the most logical urban form policy is that the nodes of these networks, should be allocated for higher density and mixed use.

In contemporary urban context, the three characteristics of compact city can be articulated by transit-oriented development (TOD) strategies. TODs - before that were called that came into existence almost 200 years ago, as soon as public transport (PT) in its initial form started appearing in fast growing cities of Europe and Asia, after walking the new urban distances became impractical. But in its modern version, under the 'TOD' label, the concept is about 50 years old. It can be traced back to American planners who tried to offer alternatives to the seemingly endless expansion of the suburban development in the North American metropolitan areas. Since the late $20^{\text {th }}$ century the model has been accepted in theory, policy and actual practice in other parts of the world, as the low density, sprawling suburbanisation became a global phenomenon.

The main strategy of TOD is densification - transforming low-density and car-oriented urban development forms into inclusive, compact, and people-oriented cities (Marks, 2016). This strategy has driven the verticalisation of cities in accommodating population growth. There are several examples around the world in which TOD has influenced the verticalisation of the 
city such as Singapore, Curitiba in Brazil and Arlington County in the USA (OECD, 2012). In Singapore, TOD strategies have successfully delivered a liveable compact city with sustainable growth (Chye, 2019). Opportunities to translate and transfer such TOD strategies into other urban context can be seen in cities like Jakarta, Indonesia and Auckland, New Zealand.

The future of TOD is bright, because most big cities are still growing and the pressure for more accommodation is relentless. The pressure is for cities to grow both out and up, and while the former is faster and cheaper, the central areas remain more attractive as a location and the pressure is now building up for 'intensification'. Intensification (or 'densification') is now preferred by most city authorities as the way to slow down the horizontal sprawl, but rather than letting the free market decide where the new high-density will occur, they try to channel the intensification to PT nodes. Typically, these are inner city and suburban rail stations, above the ground, or under the ground.

\section{Context}

\subsection{Background of Compact City and TOD in Jakarta}

Jakarta is the fastest growing city in Indonesia. It encompasses a total land of $656 \mathrm{~km} 2$ and 9.6 million inhabitants (Indonesia Statistical Report, 2011). The prominent urban challenges - due to rapid population growth in the city - include traffic congestion, air pollution, and housing shortages. More than $1,100,000$ people commuting to the city every day results in a perpetual gridlock, which established commuter satisfaction in Jakarta as the lowest among major cities in Asia. Rapid population growth has also impacted urban spatial growth, which has created a sprawling development and converted more than 30 ha of agriculture areas and green open spaces into urban settlements (JICA, 2012). According to Jakarta SWOT analysis done by JICA to establish Greater Jakarta MPA, the urban development in the city is under pressure from insufficient infrastructure, exposure to natural disasters, and a large, rapidly expanding population. However, the large population can also be an opportunity for development since it will contribute to a robust economy (JICA, 2011).

Transit-oriented development (TOD) was introduced into Jakarta planning policy in the 1990s. The first initiation of TOD in Jakarta comes from the Ministry of Transportation, who proposed an integrated transportation concept to address the bad traffic congestion, and The Ministry of Public Works who proposed high-density housing developments around the public transport routes. The first masterplan for public transport integrating railway, light rail, and buses was proposed by The Ministry of Transportation in 1992. However, the decision from the Governor of DKI Jakarta Province for Mass Rapid Transit (MRT) only came in 2004, which inaugurated TOD in Jakarta. In 2012, the MRT project was also included as one of the fast-track projects in Greater Jakarta MPA. After years of feasibility studies and design revision done by the collaboration of the Ministry of Transportation and the MRT operator company, the project kicked off in 2013 and the first phase was completed in 2019. The first phase of the MRT provides $15.7 \mathrm{~km}$ of rail-based urban transportation with seven elevated stations and six underground stations, from the South Jakarta to Central Jakarta.

Following the completion of MRT, the Ministry of Public Works aims to expand the development of TOD, intensifying development density around the new transit stations. The TOD development in Jakarta seeks to adapt several principles such as (1) diversity; (2) 
density intensification; (3) accessibility; (4) liveability; (5) social cohesion; (6) sustainability; (7) infrastructure resilience; and (8) economic renewable. With Jakarta's housing demand currently reaching 800,000 units/year, the Ministry of Public Works and Public Housing aims to provide 50 new housing developments as TOD projects, which will be the combination of middle-up-class apartments and affordable units. The TOD development sites are planned around five existing train stations and 13 new MRT stations with mixed-use development comprising of housing, business, and commercial. The existing train stations which are planned to be developed under the Ministry of Public Works and Public Housing are (1) Pasar Senen; (2) Tanjung Barat; (3) Juanda; (4) Manggarai; and (5) Tanah Abang. The MRT operator company will undertake the TOD development in 8 new stations: (1) Dukuh Atas, (2) Lebak Bulus, (3) Blok M, (4) Senayan, (5) Istora, (6) Bendungan Hilir, (7) Setiabudi, and (8) Bundaran HI.

\subsection{Background of Compact City and TOD in Auckland}

In New Zealand, the early examples of development favouring nodes of PT are related to the development of tramway networks in the main boom towns of the mid-to-late $19^{\text {th }}$ century Nelson (1862; horse), Thames (1872; steam), Dunedin (1900; electric). They were, followed by the main three cities - Wellington, Christchurch, and Auckland.i The tramway was followed by suburban train networks in Wellington and Auckland in the early $20^{\text {th }}$ century. These nodes were rarely developed in the TOD fashion as the stations were seen as only transport-related, while housing was strictly low rise suburban and separately zoned. iii

Auckland stopped developing its suburban railway in the 1950s, after a significant change in government policy and switch of funding to motorways (Harris, 2005). TODs never took off, until very recently, in this century, when the local councils decided to pursue the compact city model of urban form, invest more in PT and develop nodes and corridors of TOD (Auckland Council, 2018). TOD in Auckland has been the strategy to accommodate the population growth since two decades ago. However, the urban intensification has just started in 2003 , since the concept is quite new.

The significant point of TOD in Auckland happened in 2003, when the new Britomart station re-open; then in 2010, when Auckland Council (AC) and Auckland Transport were formed, and then in 2016, when the City Rail Link (CRL) project started. Big improvement of TOD in Auckland happened after the governance changed in 2010 when the Royal Commission on Auckland Governance established Auckland Council (AC) as a single unity authority, replacing the Auckland Regional Council and seven territorial authorities (Blakeley, 2015). AC immediately launched the metropolitan urban limit (MUL) as the tool to control growth, so that infrastructure can be provided more efficiently. Auckland Transport, as a councilcontrolled organization, launched the Integrated Transport Management Plan which aims to build an outstanding public transport within one network. The plan called New Network prioritises in the City Rail Link (CRL), electric trains, rapid transit network (RTN), and building or revitalise stations.

AC, adopting the principles of TOD, is focusing the high density and mixed-use living options within a close proximity to reliable and frequent public transport. By focusing the urban growth on centres and transport nodes, the government also aims to reduce the usage of private cars and seriously promoting walking and cycling. There are at least 21 locations where the TOD will be applied including New Lynn, Onehunga and Avondale. 


\subsection{Singapore As the Benchmark for Liveability, Affordability and Sustainability}

The third city featured in this study is Singapore. The city-state of Singapore is widely regarded as one of the best managed cities in the world, with consistent vision and planning policy aiming for a high level of liveability, affordability, and sustainability (L-A-S). This can be seen in its planning policies: Liveable and Sustainable Cities Framework, and the 10 Principles for Liveable High-Density Cities of Singapore development. It is a relatively compact city, as this policy has been the only way to develop such big and important international city on a small island.

In terms of transit-oriented development, Singapore has a long tradition of integrated land use and transport planning - it started soon after its MRT was first proposed in 1971 (Niu et al, 2019) - and has had TODs even earlier than developed western countries. The key principles learned from Singapore TOD involve incremental development of public transport capacity; integration of land use, land ownership, and transport; management of transport demand; and leveraging innovative technologies for TOD (Chye, 2019). Beginning in 1966, Singapore initiated a programme to centralise land ownership to the state in order to enable extensive transit infrastructure development. The centralization of land ownership also enabled the government to shape long-term planning for the urban renewal, followed by periodic reviews to ensure plans remained relevant for the changing population (CLC and ULI, 2013). Today, these TODs are the vitally important hubs of the entire metropolitan transport system, including a few new town centres. Singapore MRT and TOD system is mature and can be taken as the template for cities far behind, like Jakarta and Auckland.

Singapore also proves how high density can be used as an advantage to provide L-A-S to the city. Having a population density of over 7,000 persons per square kilometre, Singapore maintains a high ranking in liveability surveys - for example, Mercer's 2010 Quality of Living Survey (CLC and ULI, 2013). This paper uses Singapore planning policies as the L-A-S benchmark.

\section{Methodology}

\subsection{Case Study Selection}

The two case studies were selected based on the original, and the current place of residence and studying of the first author of this paper. She is familiar with both Jakarta and Auckland, both as a citizen-participant and a researcher-observer. The other obvious reason for the choice of Jakarta is that the ISOCARP Congress in 2019 is in this city. That makes this case more interesting for a large portion of the Congress delegates - not only the local planning professionals, academics and government officials, but also to the international visitors who want to see and understand Jakarta in the few days of their visit.

Looking globally, one could also argue that Jakarta, being one of the biggest city in the world, still growing fast, and being in a developing country is typical of the urban problems today. From a purely research perspective, the choice of Jakarta and Auckland as a pair offers a good mix of differences and similarities. The differences probably amplify the global relevance of the results; the similarities should enhance the reliability and accuracy of the results. The following table explains the differences and similarities of both cities. 
Table 1 Differences and Similarities of Jakarta and Auckland

\begin{tabular}{|c|c|c|}
\hline & Jakarta & Auckland \\
\hline Area & $661,5 \mathrm{sq} \mathrm{km}$ & $1,086 \mathrm{sq} \mathrm{km}$ \\
\hline Population & 10,638 million & 1,657 million \\
\hline $\begin{array}{l}\text { Population } \\
\text { Density }\end{array}$ & 4,383 people/sq km & 1,210 people/sq km \\
\hline Urban form & Radial-concentric & Linear conurbation \\
\hline Climate & Tropical & Temperate \\
\hline GDP per capita & $\$ 10,641$ & S35,152 \\
\hline City government & $\begin{array}{l}\text { Ministry of Land and Spatial } \\
\text { Planning } \\
\text { Ministry of Public Works and } \\
\text { Public Housing } \\
\text { Ministry of Transport }\end{array}$ & Auckland Council \\
\hline Planning system & $\begin{array}{l}\text { DKI Jakarta Provincial Spatial Plan } \\
\text { No } 1 / 2014\end{array}$ & Resource Management Act \\
\hline Long term plan & DKI Jakarta Spatial Planning 2030 & Unitary Plan \\
\hline
\end{tabular}

Source: Indonesia Statistic 2011 \& NZ Statistic 2013

\subsection{Data Collection}

The main sources of information in this study are gathered from: (1) government documents such as policies, regulations, reports, plans and maps; (2) professional and commercial documents such as planning publications, property development plans, company annual reports; (3) research literature such as books, journals and conference; and (4) public news/general media; (5) site visits/field observations.

\subsection{Comparative Assessment}

To understand the extent to which TOD policies are achieving liveability, affordability and sustainability in the context of Jakarta and Auckland development, the research uses a qualitative methodological approach. The approach includes a critical review of key reports and project intentions, followed by a comparative assessment of TOD concept policies in both countries. Considering the limitation of the research, the analysis of TOD concept policies in both countries focuses on two concrete areas - Dukuh Atas and Lebak Bulus in Jakarta; and New Lynn and Onehunga in Auckland.

The analysis of source material is done using the comparative assessment on three criteria: liveability, affordability and sustainability (L-A-S), and it takes Singapore city-state as a benchmark. This research focuses on L-A-S goals from Singapore planning policies to assess the TOD projects in Jakarta and Auckland including (1) Liveability - walkability, density, diversity and public facilities; (2) Affordability - long-term planning and housing supply; and (3) Sustainability - green open space, carbon reduction, and resilient infrastructure. 


\section{Findings}

\subsection{TOD in Jakarta, Indonesia Location}

TOD project sites in Jakarta are planned according to the location of transit stations, both the existing ones, and the new ones. Considering the limited scope of this paper, the analysis will focus on the TOD planned in the new MRT stations. After 13 new mass rapid transit (MRT) stations were completed earlier in 2019, the operator of the services - PT. MRT Jakarta - along with the government plan to continue with TOD development, prioritised around 5 MRT stations, including Dukuh Atas and Lebak Bulus.

Lebak Bulus Station is the first elevated MRT station - connecting South Jakarta to North Jakarta - and is expected to be the new transport node for people commuting to Jakarta. As the starting station, the development of Lebak Bulus TOD will determine the whole project of MRT Jakarta (JICA, 2015). Dukuh Atas Station is the underground MRT station located in Central Jakarta. This is a strategic location due to its close proximity to Jakarta CBD, the famous Hotel Indonesia roundabout, and Sudirman Station (commuter line). Dukuh Atas area will soon become the largest urban transportation hub in Indonesia, integrating six transportation services such as MRT, Transjakarta Bus, commuter line, airport train, and LRT. Lebak Bulus and Dukuh Atas TOD projects are planned to be the regional urban core in Jakarta. Both projects are under the same company operator and generally using the same strategies.

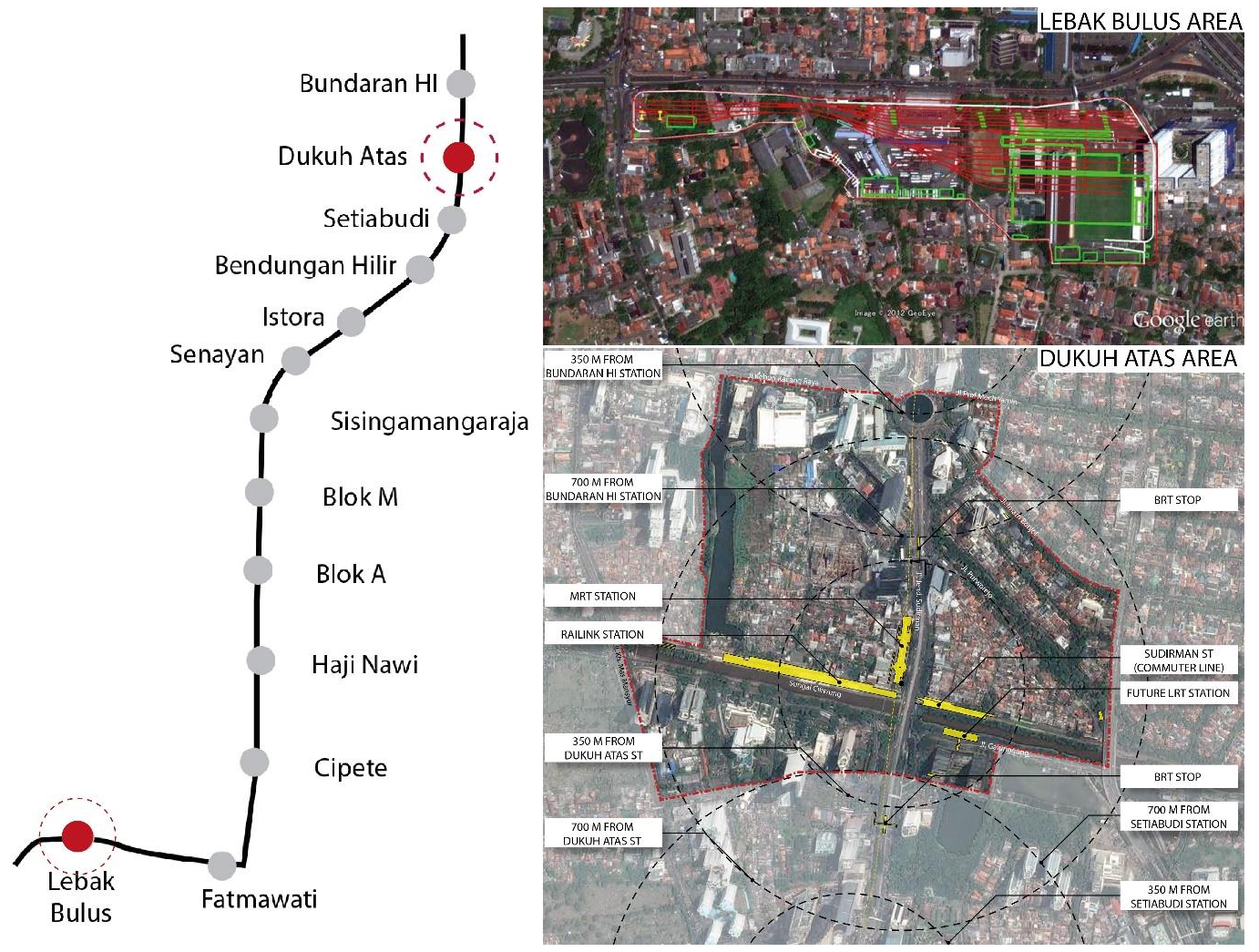

Figure 1 Jakarta TOD Areas (JICA, 2015; PDW, 2019) 


\section{TOD Strategies}

TOD strategies in both areas involve densification, accessibility, connectivity and green open space. In Dukuh Atas TOD, the strategy for densification is increasing the floor area ratio (FAR). Based on the UDGL 2012, FAR for buildings along the Sudirman Street will be raised up to 6.0 from the current $1.8-4.5$. The FAR structure has four different layers according to the distance from transit stops, where buildings inside 800-metre radius from transit stops have the maximum FAR to 12.0 while buildings outside 1,200-metre radius from transit stops have the maximum FAR to 3.5. Areas inside 400-metre radius from transit stops with the highest FAR will be the priority for mixed-use development combining business, commercial and residential. Same strategies also applied in Lebak Bulus TOD to provide higher density with diversity of uses. The development focuses on the 14-ha site located in 500-metre radius from the station accommodating residential, businesses, and retails. Thus, the significant transformation from the densification can be seen on the verticalization along the transit corridor in both areas (Figure 2).
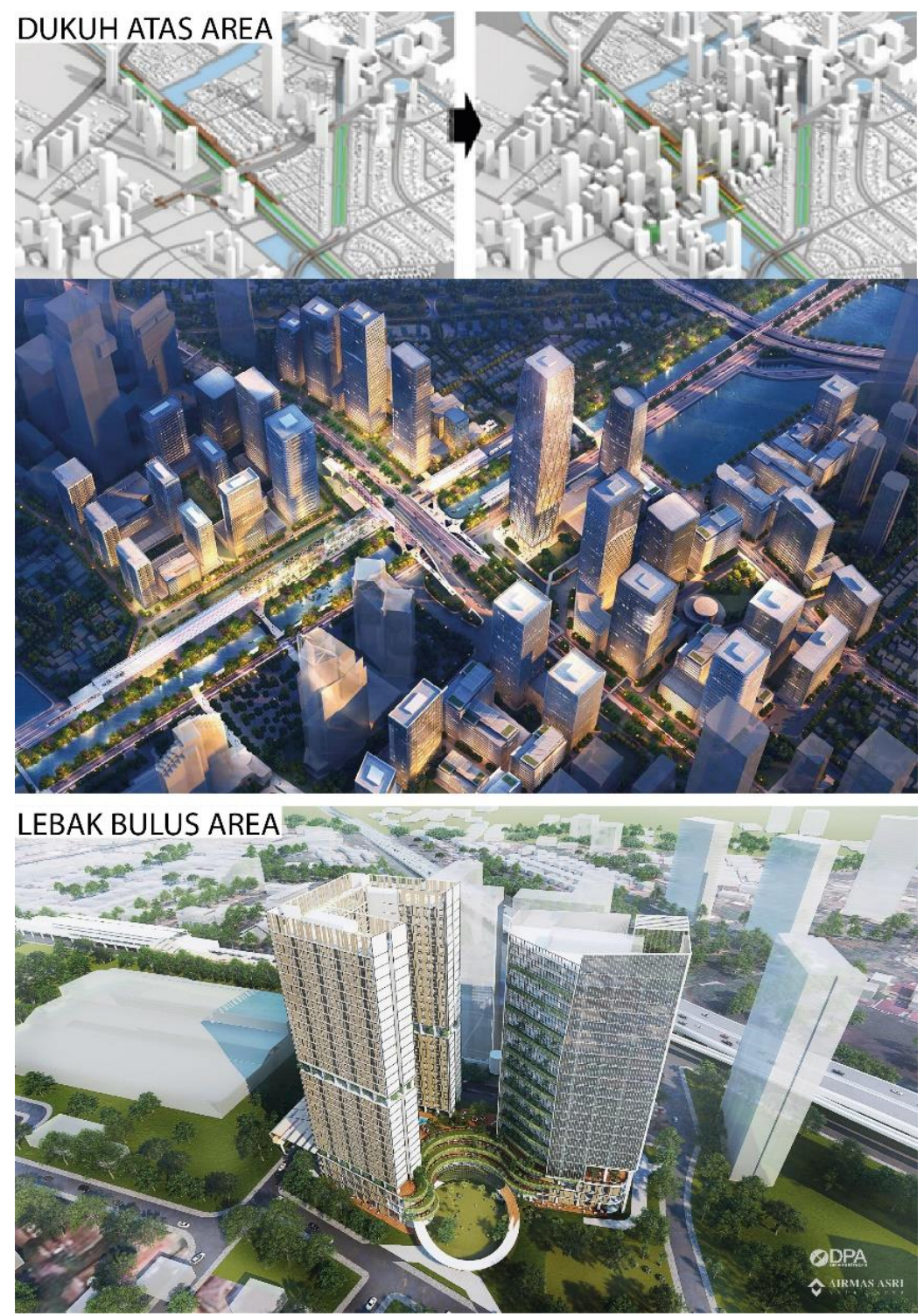

Figure 2 Verticalization in TOD Areas (MRT, 2017; Totalindo, 2018) 
Pedestrians are fundamental to achieve liveability in TOD projects. In the existing condition of Dukuh Atas, pedestrian activities are generally concentrated around Sudirman Station (commuter line) and can reach more than 5,000 people/hour during peak hours. According to the masterplan, pedestrianisation in both areas will be focused on providing different types of pedestrian movement and activity, with cycleways, a pedestrian bridge, a pedestrian tunnel, and street-level pedestrian facilities. This strategy aims to improve the permeability of pedestrian networks and provide ease of changing between public transport modes. The street level pedestrian spaces which were previously considered unfriendly are planned to be revitalized by adding disabled access, street furniture, and shading. The pedestrianisation then followed by the creation of great streets within 100-metre radius from transit stops. The great streets approach will intensify activity around the mixed-used developments along the transit corridor, through direct pedestrian access from the transit stops. This strategy also aims to improve the local economy of both areas.

In Dukuh Atas, there is a recently completed pedestrian tunnel under Sudirman overpass, connecting Sudirman Station to MRT Station and Airport Railink Station. Before the redevelopment made it pedestrian only, this tunnel was filled with private vehicles heading towards the CBD area. In the centre of the four quadrants, the main pedestrian bridge is planned to connect the whole area of Dukuh Atas. However, in Lebak Bulus, many public news reported that the pedestrian is considered unfriendly with lack of canopies and street lighting.

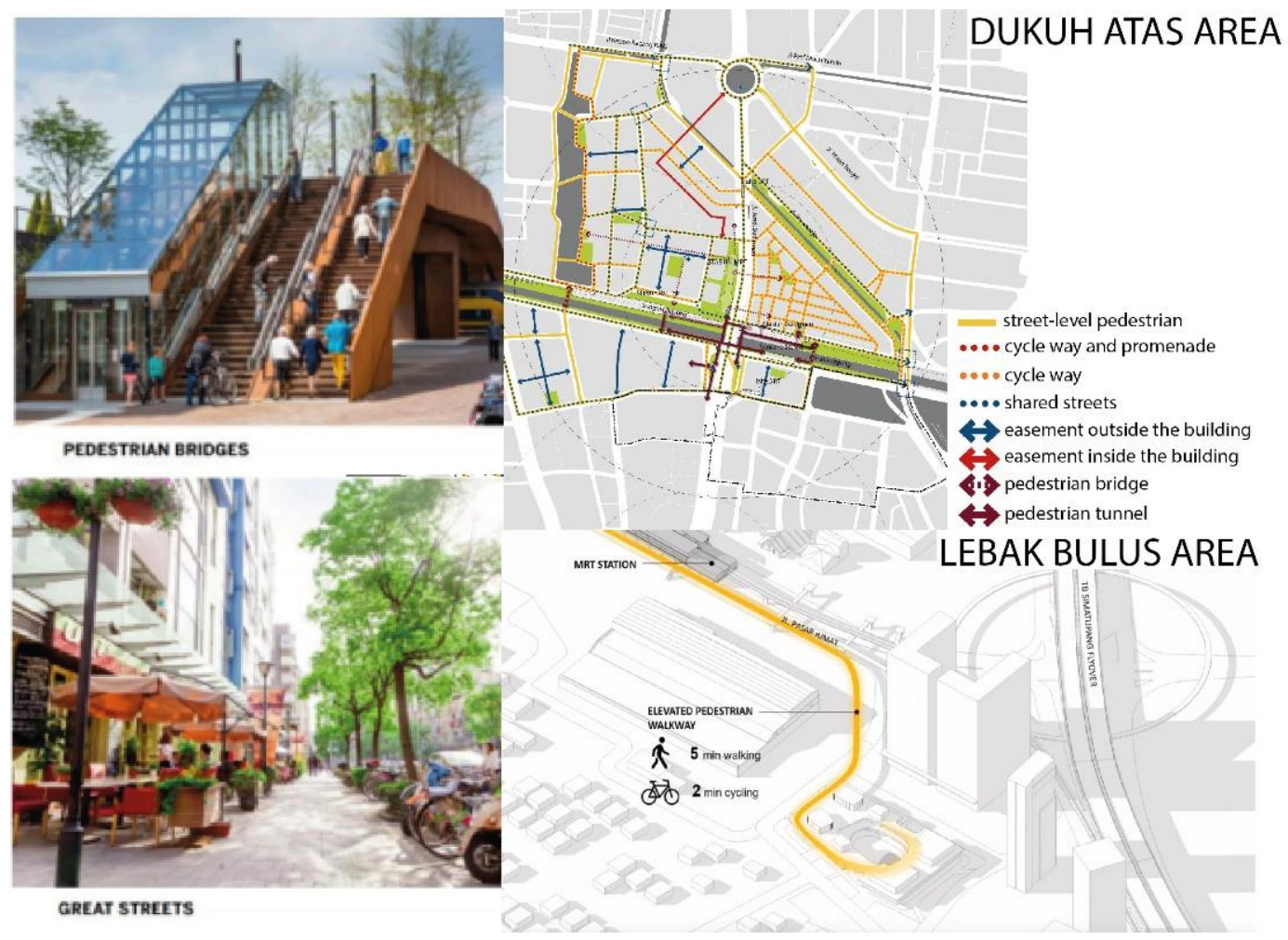

Figure 3 Walkability in TOD Areas (PDW, 2019; Totalindo, 2018)

The next strategy is connectivity which translates in the integration of transport hubs for ease of changing public transport modes within the area. The masterplans show that transport hubs will also be integrated into a park and ride facilities accommodating more than 300 vehicles and developed into mixed-use facilities supporting retail tenancies, 
businesses, and public spaces. In Dukuh Atas, new transport hubs are planned to connect six public transport modes in four areas, which are (1) MRT station, (2) Blora market, (3) BNI Tower, and (4) Landmark Building. In Lebak Bulus, the MRT station is integrated into the Park and Ride facilities.

The next important strategy is the placement of green open space in TOD areas (Figure 5). The masterplans show that the preservation of green open space is combined with the creation of public space. The strategy includes the place making of a civic plaza and a renewal of the Ciliwung River corridor in Dukuh Atas area. In Lebak Bulus, it is also planned to provide different kinds of public open space inside the mixed-use development such as outdoor café, event plaza, multi-layered terrace garden, and semi-outdoor courtyard.

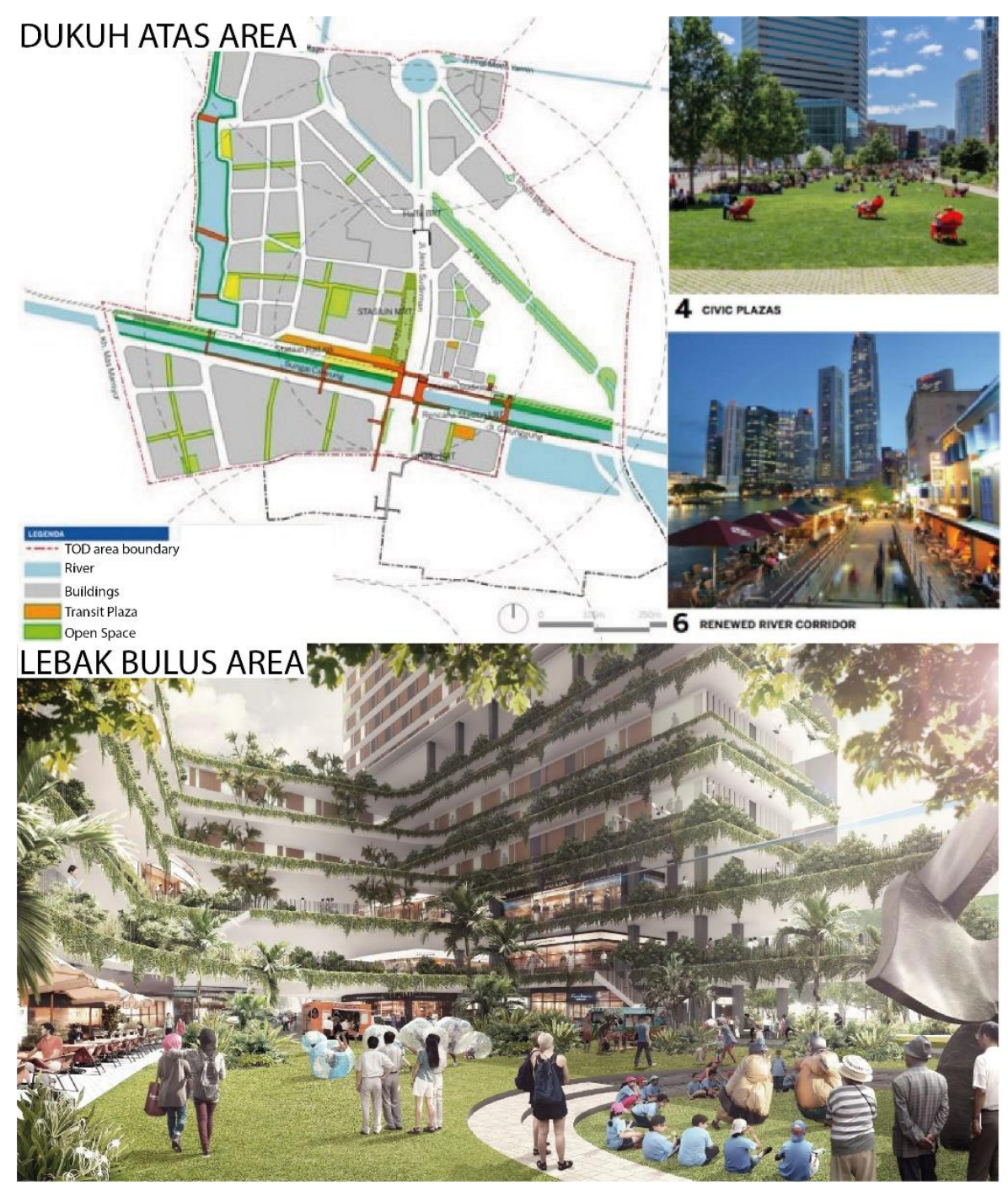

Figure 4 Open Space Strategy (MRT, 2017; Totalindo, 2018)

One civic plaza example can be seen from the Dukuh Atas Garden which located above the recently completed MRT station. Dukuh Atas Garden is a revitalisation project since the MRT station was built on the existing open space. The aim of this garden is to be a new node in the area where community activities can take place. Upon the completion of the project, Dukuh Atas Garden seemed to accommodate many public events and improved citizens enjoyment, supporting liveability (Figure 6). The next strategy in Dukuh Atas is the renewal 
of the Ciliwung river corridor which is located at the centre of Dukuh Atas TOD area and divided the four quadrants. The intention of the renewal is to improve the riverbank area and support more activities along the river corridor, accommodating retails and public space, and a new river walk connecting the riverbank to the pedestrian bridge in Sudirman Street.

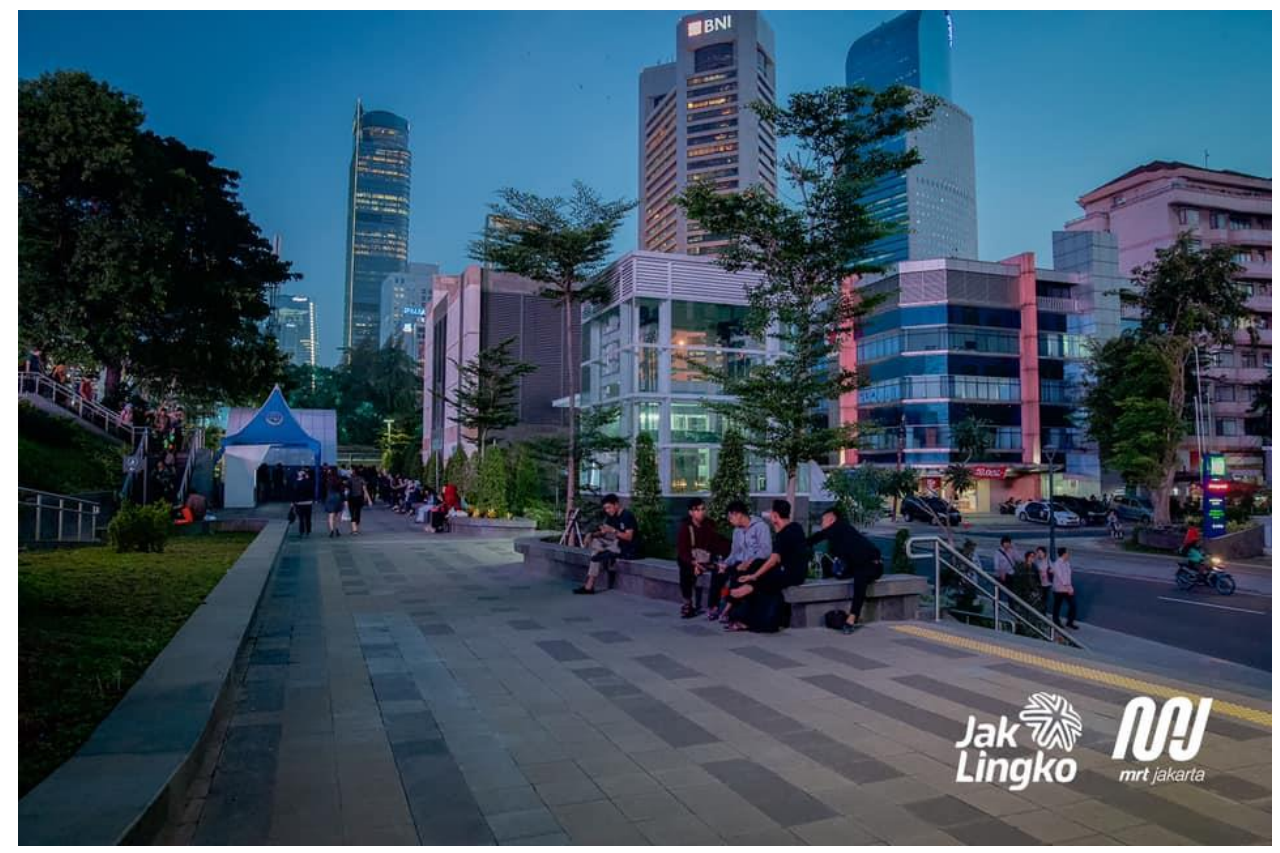

Figure 4 Civic Plaza in Dukuh Atas TOD (MRT, 2017)

\subsection{TOD in Auckland, New Zealand}

\section{Location}

There are some areas planned for urban intensification using TOD as stated in Auckland Plan 2050. These areas usually designated for town or metropolitan centre with high-density development, which integrated through strategic public transport network, including New Lynn and Onehunga.

For New Lynn TOD, AC going through a characteristic study of TOD versus the adjacent development to determine the opportunity and constraint of the projects. The study outlined that the existing condition such as suburban street pattern, low density, parking area dominance, unfriendly pedestrian space, and segregated land use are the weaknesses that planned to be improved using TOD strategies. New Lynn TOD is the first part of the district's transformation and one of the largest urban regeneration projects in New Zealand. The project starts with the completion of the new transport interchange which since then has been followed by range of projects including town centre's revitalisation, open space upgrade, and high-density housing development. These new developments establish New Lynn, which was neglected before, as one of the most important town centres in Auckland, accommodating people who work close to home, living in vertical housing, with options of public transports, also walking and cycling to get around. New Lynn is claimed to be Auckland's first true TOD.

Onehunga is one of the areas outside CBD that designated for higher density development and town centre targeted for transit-oriented development, as defined by AC. In 2014, a new 
town centre and a perimeter block comprises 112 units were completed. This town centre is identified to be the future population and employment growth. In 2017, AC, through Panuku, another council-controlled organisation, launch a High-Level Project Plan (HLPP) for Onehunga which aims to transform the district into a TOD area. This project will be a longterm development, build on the existing potentials around the town centre.

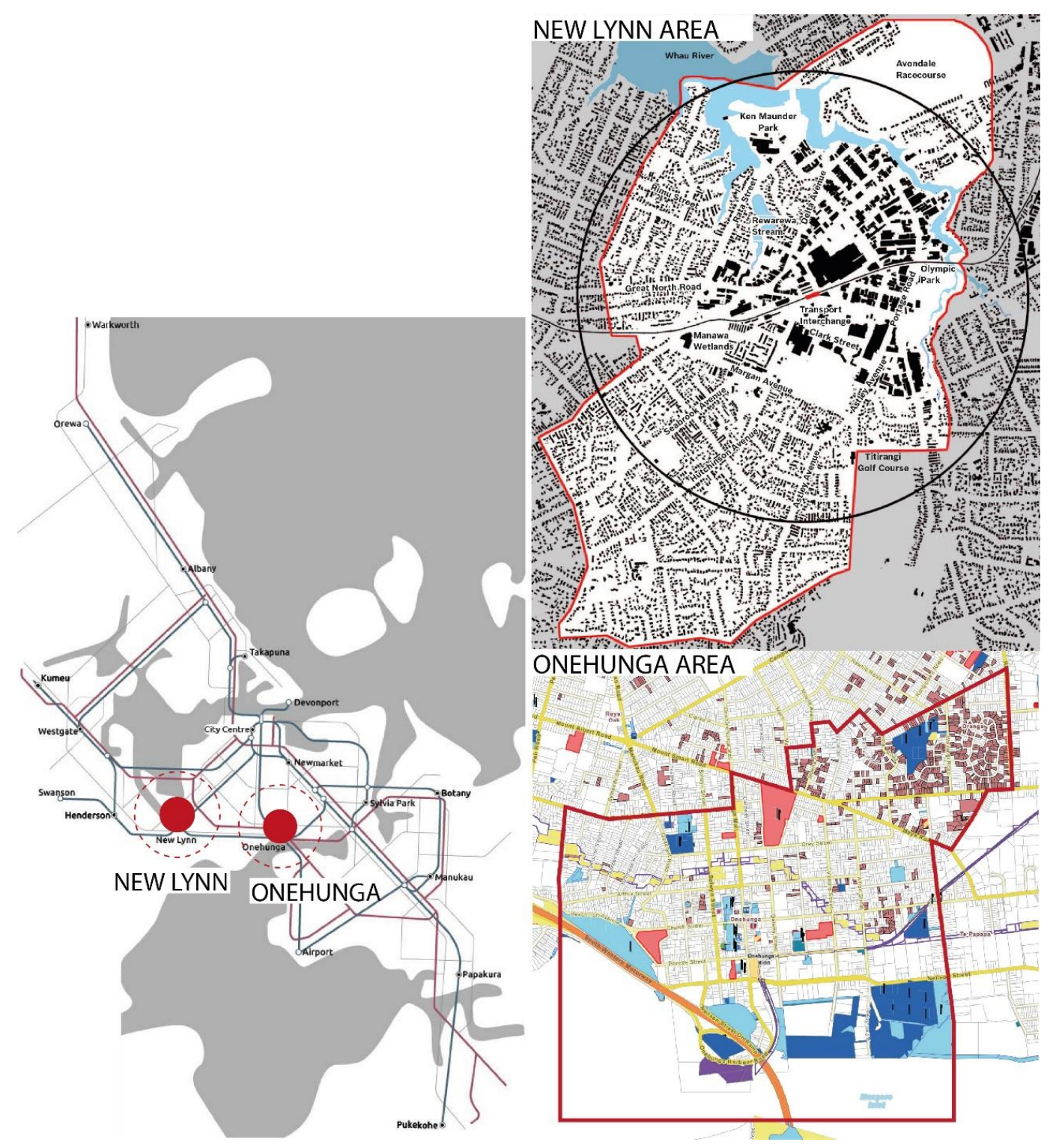

Figure 5 Auckland TOD Areas (New Lynn UrbPlan, 2010; Panuku, 2017)

\section{TOD Strategies}

The TOD strategies in both areas include (1) densification; (2) open space strategy, (3) movement and connectivity strategy, and (4) social and economic strategy. The densification strategy starts with planning priority sites for development and dividing them into precincts according to the timeline, such as high priority sites, medium-term opportunities, and longer-term opportunities. There are 10 precincts in New Lynn and five precincts in Onehunga. The densification focuses on providing mixed-use development, high-density housing, and redevelopment of the existing industrial block. In New Lynn, the densification can be seen from mixed-use development in Merchant Quarter, Crown Lynn and The Mall 
precincts accommodating 12 ha business area, more than 2000 new residential units, and 9ha new retail area which located within 400-metre radius from the transit interchange. In terms of housing, the development uses a 'carrot and a stick' approach, which limiting the suburban-style development and transforming it into a compact urban living. The densification aims to create New Lynn as an urban place centred on a transit interchange, accommodating 20,000 residents and 14,000 workers in 2030 (New Lynn Urban Plan, 2010).
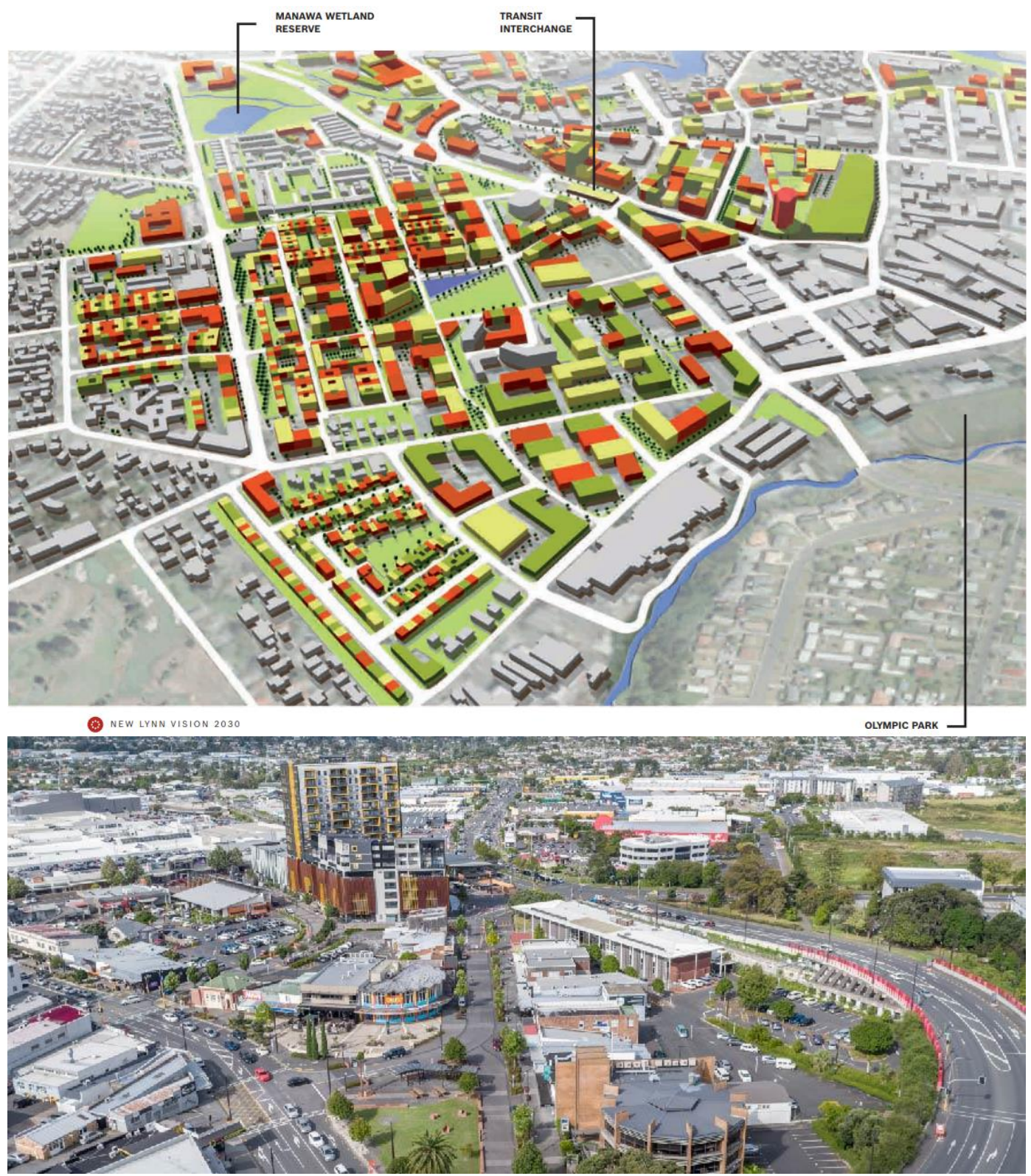

Figure 6 New Lynn densification area (New Lynn Urban Plan, 2010)

In Onehunga, the densification is planned to address the growth projection and the changing market demand from predominantly conventional freestanding family housing into mediumdensity housing. Similar with New Lynn, densification in Onehunga is also providing various mixed-used developments integrated with public transport and concentrated in town centre core precinct for short to medium term. The precinct has existing potentials including retail, businesses and train station, in addition to which are planned 650 new dwellings and more than 15 ha of new commercial and businesses spaces area (Panuku, 2017). In terms of 
housing, there are several Special Housing Areas (SHA) sites in Onehunga. SHA is a housing development policy which establishes fast-track housing development sites and encourages private sectors to develop. Both in New Lynn and Onehunga, densification focused in the town centre is expected to be the catalyst for future developments due to land ownership. The development in town centre is expected to be easier and faster, since most of the council's land is located there.

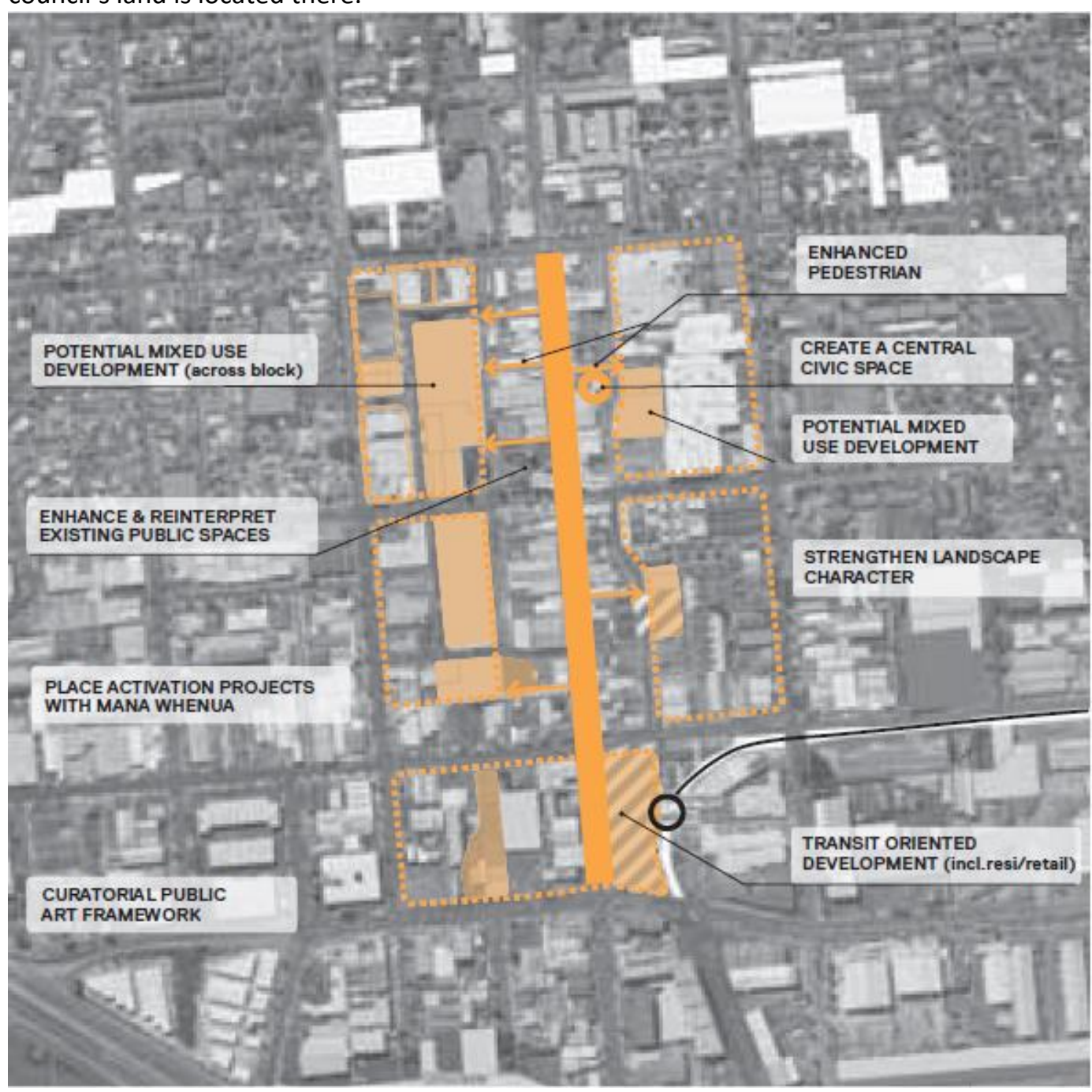

Figure 7 Onehunga densification area (Panuku, 2017)

The next important strategy in both areas is the open space provision, since Auckland is a coastal city abundant with natural heritage. In New Lynn, the open space strategy is called the 'power of ten' which includes the preservation of five 'hard' and five 'soft' spaces within 500-metre radius from the transit interchange. This strategy is implemented through maintenance and improvement of the existing open spaces. This approach also aims to improve the connection between open spaces through high-quality pedestrian areas which are centred in New Lynn Park, a large (one hectare) urban park in the Crown Lynn precinct.

The next open space strategy is to create a green-blue loops and links which link river streams to green open spaces and open the river corridors for public activities. Besides open spaces, the Whau River and the Rewarewa Stream are another important natural features which are often neglected. In addition to this strategy, streets in New Lynn are also designed to be green streets lined by trees with generous footpaths widths and cycle way. These open 
space strategies are also being included in the development design guidelines. For example, all new housing developments will be required to front onto the river or green streets. Also, housing development more than 10 units shall be located within 200-metre radius from public open space.

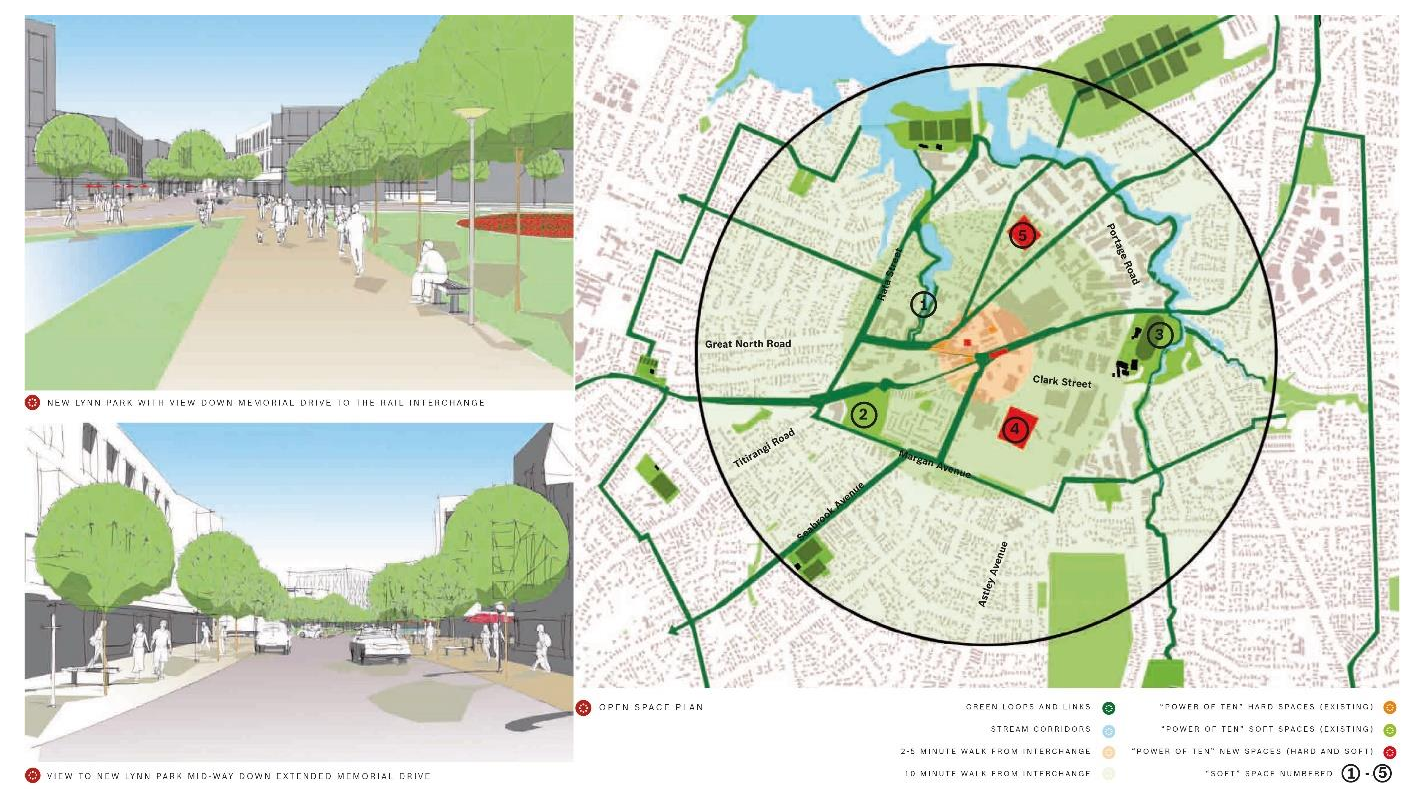

Figure 8 New Lynn Open Space Strategy (New Lynn Urban Plan, 2010)

The open space strategy in Onehunga is heading to the same direction with New Lynn, it aims to improve people's well-being through the enhancement and restoration of the natural environment. The strategy includes the improvement of green-blue networks enhancing the value of Manukau Harbour and its foreshore through the redevelopment of Onehunga's waterfront as public open space. The waterfront is planned to be the new recreational and cultural destination promoting ecological corridors for public use.

The third strategy is about movement and connectivity which are fundamental to the success of TOD project. According to the New Lynn 2030 vision, the area aims to be a showcase of pedestrian and cycle friendly place. The framework plan established a transport hierarchy to place pedestrians as the top priority together with cyclist and public transport while private vehicles become the least priority. The walkability is planned through a detailed design guideline including the $1.8 \mathrm{~m}$ minimum width, crossing facilities every 100 metres, and the street lighting improvement. This strategy is also the continuation of the green street strategy to improve pedestrians by planting trees along the footpaths and providing street furniture.

The cycling network is planned to be integrated within two $\mathrm{km}$ of the transport interchange. The existing street transformation was done into 3 different types such as shared path, slow street and calmer street. The cycling plan is complemented by the provision of cycle stands and storage lockers with 1:4 ratio (one cycle stand for four car parking space). The cycle racks also planned to accommodate rentable bikes offering cycling opportunities for visitors arriving in New Lynn by train or New Lynnians who do not own a bike. In order to be a sustainable TOD area, the movement strategy also manage the limited car parking provision in the area using 1:40 ratio (1 car park space per $40 \mathrm{sqm}$ of floor space). Onehunga also planned similar initiatives with New Lynn by targeting key streets to be transformed into 
pedestrian and cyclist friendly environment, and reduced vehicle movements. The recent investment of cycling facilities can be seen in the cycle lane in Onehunga Mall. The cycling network is also planned in the foreshore, connecting the town centre to the Onehunga Wharf.

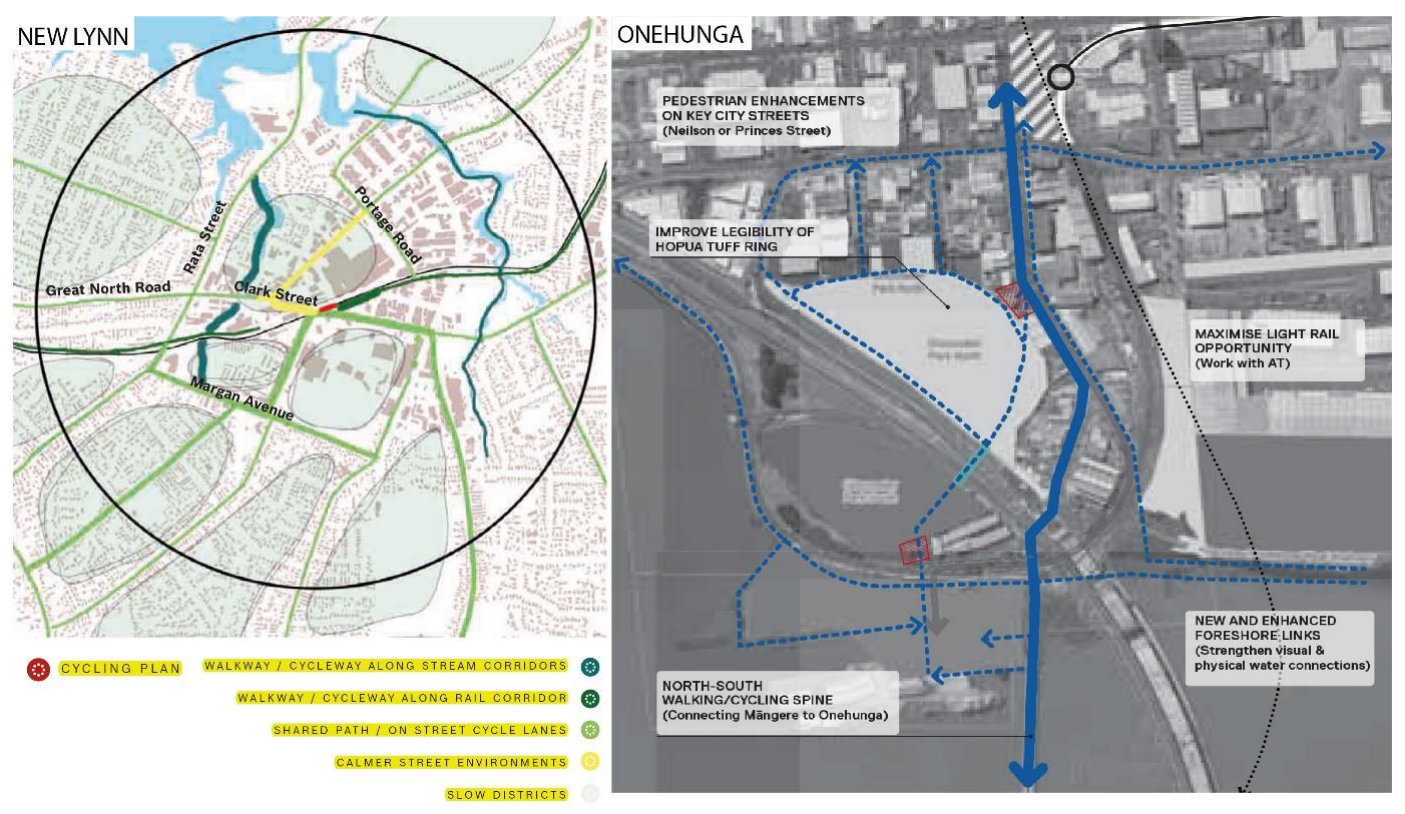

Figure 9 Movement and connectivity strategy (New Lynn Urban Plan, 2010; Panuku, 2017)

The last TOD strategy is regarding social and economic aspect. Part of the New Lynn 2030 vision is to improve the social and economic conditions through the provision of affordable housing integrated with community facilities and a high-density employment hub. To achieve the affordability, housing development in New Lynn is planned to have a mix of quality housing size and form to retain the current diversity of the existing community. The next step of providing affordable housing integrated to the community facilities such as primary schools, local shops and civic anchors. Strong economic base is also the critical part of the successful TOD in New Lynn and this is planned to be achieved with the creation of new employment and commercial hub focused on precincts close to transit interchange: Merchant Quarter and Crown Lynn. In Onehunga, the social and economic strategy focuses on retaining the existing commercial activities around the town centre and revitalising the existing industrial area to be a mixed-use employment precinct. 


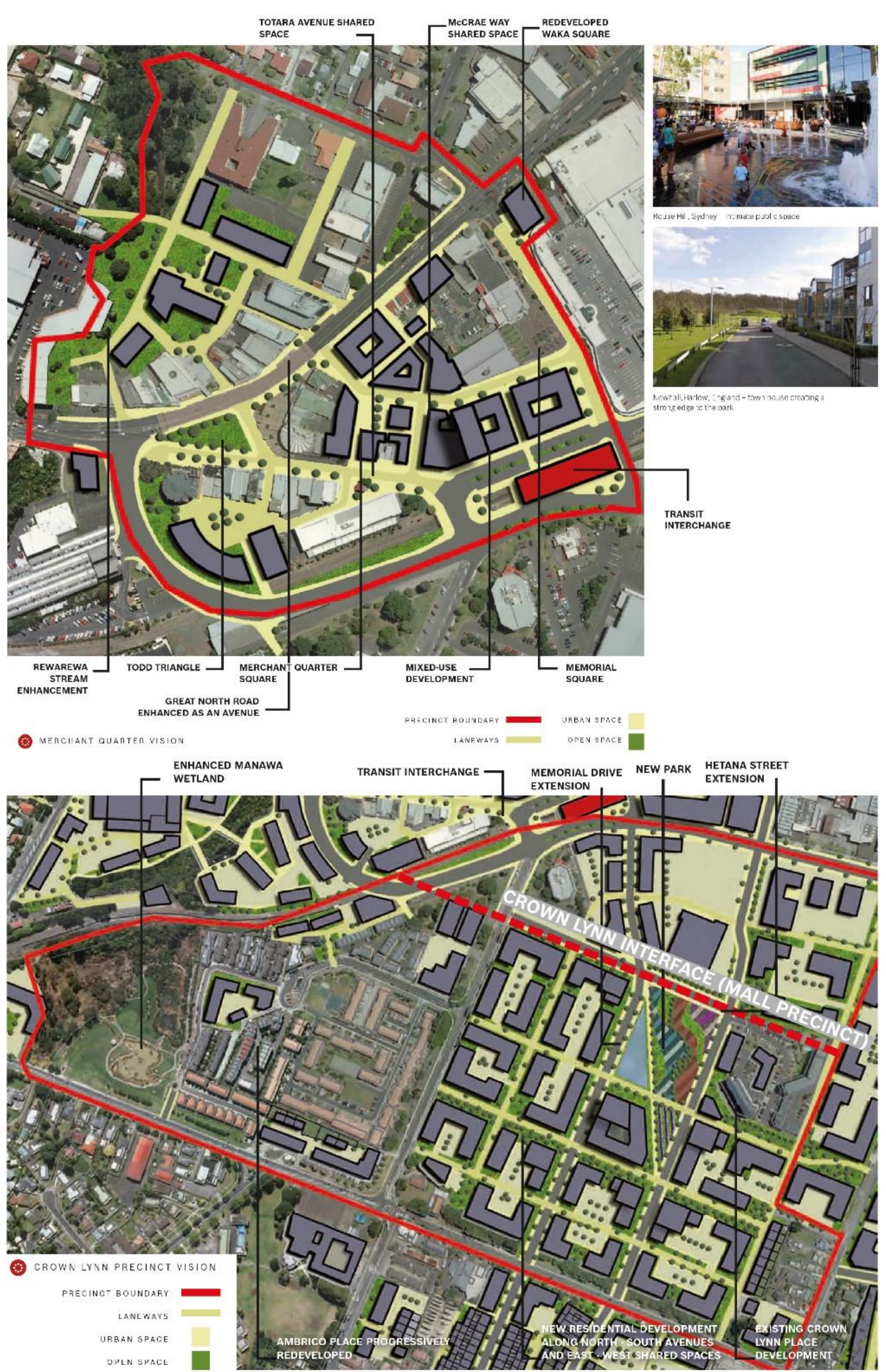

Figure 10 New Lynn social economic strategy (New Lynn Urban Plan, 2010) 


\subsection{Comparative Assessment}

\section{The Liveability}

To understand the extent to which TOD strategies in Jakarta and Auckland are achieving the liveability, the research focused on the walkability, densification, diversity, and public space provision.

\section{Jakarta}

In Jakarta, pedestrian networks in TOD areas have been planned in detail to improve pedestrian accessibility and provide shorter trips. However, implementation will be constrained by the fact that the development will be done on the existing, active built environment and overlaps with other projects. For example, in Dukuh Atas, the transit stops have been fully in operational while the pedestrian facilities are still under construction. The same thing happened in Lebak Bulus, since the MRT station is fully operated but many complaints that pedestrians to the station and park and ride facilities are currently inadequate. The cycling facilities, which are should come as one package with the pedestrian networks, will also need more detailed planning in a macro scale providing the ratio of bike rack and storage, and the continuity of bike lanes outside the 500-metre radius from the station.

The next issue relates to land-use planning in Dukuh Atas TOD, which is still predominantly segregated between residential and public amenities, similar to the existing condition (Figure 11). While some of the existing residential areas on the west side of Sudirman Street are being transformed into a mixed-use zone, the remaining residential areas are still located behind the business zone and outside the 400-metre radius from transit stops. The segregation of residential area and public amenities can reduce liveability and exacerbate social injustices, which may also lead to the Jakarta-typical slum problems in future developments. The TOD area also need a sufficient amount of high-quality public space to be successful. The TOD strategies of Dukuh Atas and Lebak Bulus usually integrate public space with the transit-hub and green open spaces. The new Dukuh Atas Garden above the underground MRT station is a good example of public space in TOD area. This example should be used as a reference in other TOD areas.

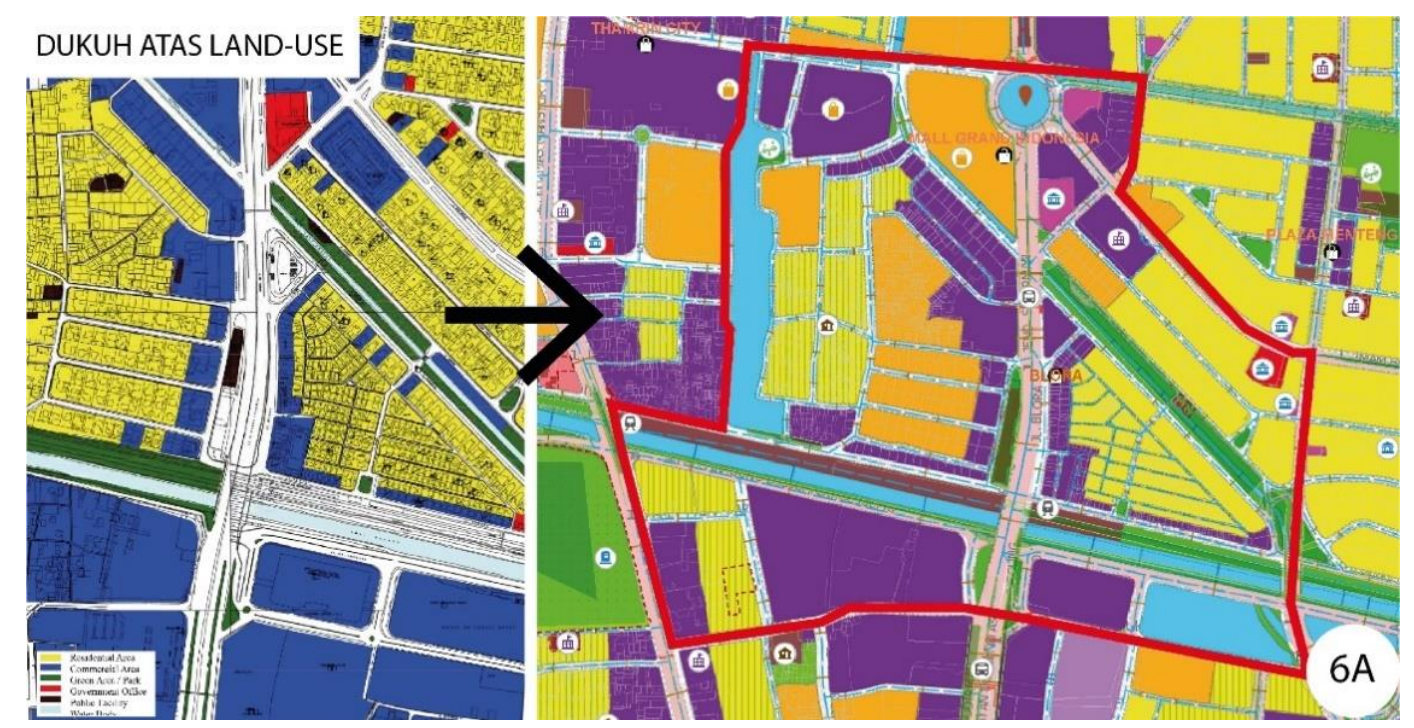

Figure 11 Dukuh Atas land-use plan transformation (Jakarta Spatial Plan, 2011) 
In terms of densification, the strategy to verticalize and intensify are constrained by land acquisition, because most of the land in Jakarta is under private ownership. In Dukuh Atas, for example, the government is currently own the green open spaces and the existing market in Blora Street only, which resulted in slow progress of development since the land acquisition process usually take a long time. The densification is also sensitive to vertical transformation since culture and lifestyle preferences in Indonesia are still not adjusted to vertical living. Failed verticalization can be seen from the previous attempts by the government to relocate the people living in low-rise high-density residential settlements, known as kampong into affordable vertical housing. In 2015, people who live in Kampung Pulo were evicted and moved into vertical housing development called Rusunawa Jatinegara Barat. However, public news reports based on interviews with residents stated that they now face numerous problems in the vertical housing contexts, such as poor building quality, lack of living space, unaffordable rent; and decreased income due to lack of space for their kiosks. This evidence shows that there is a lack of specific design guidelines and monitoring function of the vertical housing development.

\section{Auckland}

In Auckland, pedestrian networks in TOD areas also have been planned thoroughly encouraging people to walk and cycle. The robust planning shown in New Lynn 2030 vision is the showcase of pedestrian and cycle friendly place. The vision is followed by various strategies like transport hierarchy prioritising pedestrian and cyclist, green streets, cycling infrastructure, also bike renting. The pedestrian networks also completed by the right amount of diversity of land uses, for example, Merchant Quarter and Crown Lynn precinct in New Lynn. For the public space provision, both New Lynn and Onehunga have large amount of existing open public space that can be improved, since the current conditions have been neglected.

In terms of densification, Auckland is facing a similar problem with Jakarta which is land acquisition. The limitation of land owned by government resulted in the slow progress of urban development, while the housing crisis in Auckland keep getting worse. This is also the reason behind the emerge of SHA policy encouraging fast-processed developments. The other issue of densification is regarding the people's traditional lifestyle. Most Aucklanders prefer to live in a free-standing family housing, rather than in a high-rise apartment. The verticalization of housing is a new concept in Auckland, since the urban intensification has just started in 2003. One of the strong public reaction towards the verticalization is called 'not in my back yard' (NIMBYism), where people usually rejected higher-density development near their area. This public pressure made AC reducing height limits and density in new housing developments (Blakeley, 2015). The NIMBYs also caused many proposed development projects never took off (Donovan, 2013) and show the low ability to integrate new people into the existing community as the area intensifies.

\section{Singapore}

Singapore was able to create dense developments that were both functional and liveable as the result of integrated master planning and development and dynamic urban governance (CLC, 2014). The city provides ease of travel by walking and cycling through detailed and continuous strategies like "Walk2Ride" programme which integrate 88 MRT and 38 LRT stations with high-quality pedestrians and Walking and Cycling Plan (WCP) that must be included in each new development (LTA, 2018). The built structure also designed according 
to the measure of comfortable walking distance - for example - in Marina Bay, blocks are designed in a grid structure with manageable size and underground walkways between buildings (Ollivier and Djalal, 2017).

Regarding land acquisition, the government approach that can be learned from Singapore is the integration of land ownership since 1966, through its "1966 Land Acquisition Act", from which it now owns more than $90 \%$ of land in the country. Dominating urban land ownership has enabled the Singaporean government to coordinate multiple urban developments. This can be a good example for urban development in Jakarta and Auckland. The verticalization was done in accordance with "Housing \& Development Act of 1960" which succeeded in achieving that $82 \%$ of Singaporeans lived in HDB apartments in 2015 (HDB Annual Report, 2015). This policy sets up design guidelines in providing a liveable vertical housing, setting standards for water supply, sanitation, building materials, and access to public amenities.

In terms of land use, planning guidelines in Singapore consistently co-locate residential areas with public amenities within a 400-metre radius of the neighbourhood centre, so they can easily be reached by walking. Land in Singapore, especially in CBD areas, was parcelled to provide flexible developments. In Marina Bay, for example, land-use planning also provided a clear urban grid framework, which enabled a mix of housing, commercial and business activities within close walking distance of the CBD area (CLC and ULI, 2013) (Figure 6b). Aside from these issues, the planning of pedestrian networks in Dukuh Atas TOD is considered to have a high level of success in improving the liveability of the neighbourhood.
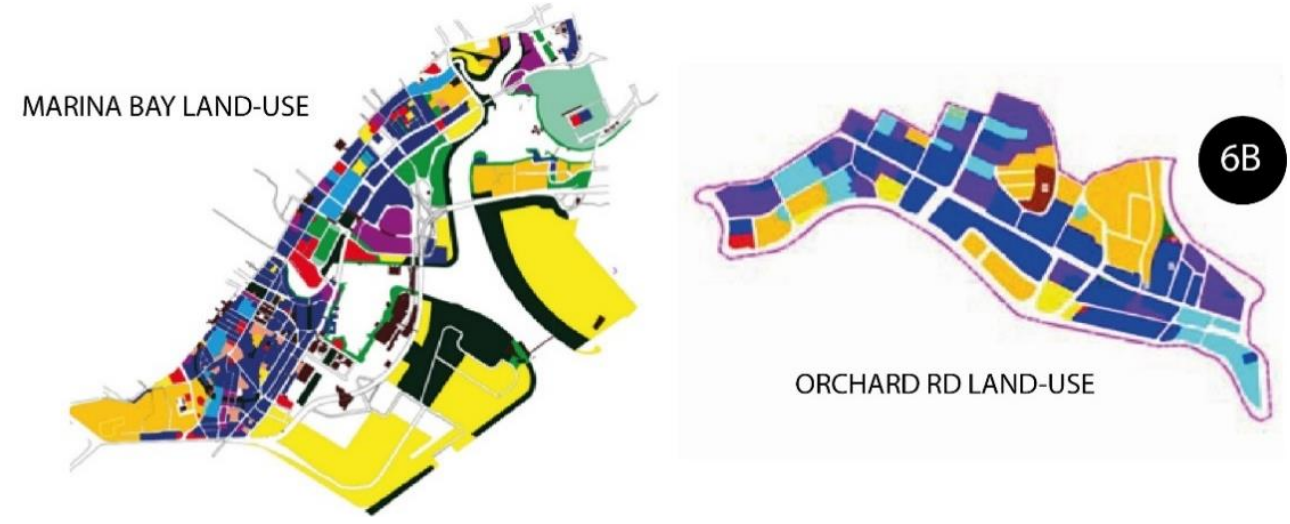

Figure 12 Singapore land-use plan (CLC and ULI, 2013)

\section{The Affordability}

To understand the extent to which TOD strategies in Jakarta and Auckland are achieving the affordability, the research focused on the affordable housing development and long-term planning.

Jakarta

The most prominent challenge of affordability in Jakarta is the lack of housing options regarding types and tenure. Also, the allocation of affordable housing in new developments is considered inadequate. According to UU 20/2011 regarding vertical housing called "rumah susun", the minimum allocation of affordable housing is $20 \%$ of the total floor area. It is not clear yet the ratio of affordable housing allocated in Dukuh Atas and Lebak Bulus TOD will be achieved since the master planning is currently in the early stage. However, we can refer to Pasar Senen and Tanjung Barat TOD which planned to be built around the existing train 
station. The development aims to provide 480 out of 1,362 units of affordable housing in Pasar Senen, and 300 out of 1,232 units of affordable housing in Tanjung Barat. Both developments allocated $35 \%$ of the total unit for affordable housing. However, it is still considered insufficient as public media observed that there are almost 15,000 people waitlisted for the allocation in affordable housing, while there are only 9,000 of available units (Kompas, 2018).

Another issue of affordability is regarding the development stakeholders. Most of the vertical housing development in Jakarta was done by private developers, for whom the importance of these projects resides in more business opportunities, rather than the provision of affordable units (Sumandoyo, 2017). The lessons from past developments have not been learned - Kalibata City, which was originally declared as affordable housing in the built permit, was eventually built into a medium-high class apartment by private developers. This apartment complex is facilitated by parking lot, anchor retails from big brands and is located in the town centre area. This is in contrast with the affordable housing built by the government, which usually is located far from public amenities, had low qualities, and later grew into a 'vertical-slum' (Kresna, 2017). Since the TOD areas are mostly located on expensive land in the town centre, it is quite uncertain if the new housing development can be affordable. Also, TOD masterplans are focusing more on the catalyst projects and not providing the long-term planning especially for affected areas outside the TOD site.

\section{Auckland}

According to the Auckland Plan, the housing development planning already aimed to provide flexible housing options with variations of types and tenure due to the city's diverse community. The land use planning also covered the future development of areas outside the TOD site, which shows the long-term planning in the wider-context. However, Auckland is still having a housing affordability crisis. Affordable housing is generally achieve when the median house price is three to four times the median household income, but in 2015, the median house price in Auckland is almost ten times higher than the median household income (Blakeley, 2015). This has made home ownership becoming less likely for young generations.

The challenges come from the lack of land supply, private land ownership, and densification restrictions in the planning policies as the result of public rejections of high-density developments. The demand for housing in Auckland keeps on increasing while the housing supply is low, the unaffordability persists (Blakeley, 2015). The housing development is considered slow due to expensive construction and long consenting process. The emergence of SHA did bring improvement to the Auckland's housing development by putting several sites across the city for fast-track development, but it is not as fast as needed (Harman, 2016).

\section{Singapore}

Affordable housing supply in Singapore started from the initiation of Housing and Development Board (HDB) in 1960. The main purpose of HDB is to provide public housing which affordable and yet has a high-quality. In 1959, only $9 \%$ of Singaporeans live in the public housing, but today more than $80 \%$ of them resided in HDB apartment. Each year the government sells the un-built apartments predominantly to first-time buyers which price are lower than the market price. The public housing in Singapore was designed with flexibility of types and tenure. The unit types range from two types of one-bedroom apartment, three 
types of two-bedrooms apartment, five types of three-bedrooms apartment. There is also a medium-high class unit called "Executive Condominiums" (EC) which were allocated for private developers.

The affordability is also achieved through variation of home ownership schemes to give citizens the flexible purchasing method, such as Additional CPF Housing Grant (AHG), Special Housing Grant (SHG), and Parenthood Priority Scheme (PPS). Singaporean also helped by the low instalment interest which resulted in $90 \%$ people who resided in the public housing actually owning the unit (HDB Annual Report, 2015). The housing development planning is also complemented by the public housing quota system which ensures the balanced mix of ethnicities to address the diverse community in Singapore. In addition to the housing affordability, the government also located hawker centres which is famous of the cheap price in a close proximity to the housing blocks.

Another interesting concept from planning policies in Singapore are "white sites", which are areas allocated to developers for future developments that can have flexible functions to match changing market demands. This policy helps to maintain the liveability and economic value of the sites, also encourages developers to analyse the market based on people behaviours. The fast and affordable development of public housing in Singapore is the result of long-term planning combined with responsive land-use policies and development monitoring. City planning in Singapore is based on a 50-year period of concept planning, translated into detailed masterplans for each project with a shorter time frame (CLC and ULI, 2013). Also, with $90 \%$ of the land owned by government, the affordable rent becomes feasible.

\section{The Sustainability}

To understand the extent to which TOD strategies in Jakarta and Auckland are achieving the sustainability, the research focused on the open space, resilient infrastructure, and carbon reduction.

Jakarta

Open space strategy in Jakarta can be optimized to achieve the sustainability since it has the potential to form the centre of a TOD area where public activities take place. This can be seen from citizens' positive reactions for the recently completed Dukuh Atas Garden. However, when looking at the future plans, the public open spaces are concentrated in the MRT station and along the river, while the rest of the area has an only small portion of it. The greenery strategy should be taken seriously since Jakarta has less than $13 \%$ green surface area (Jakarta Spatial Planning, 2011). The renewable river corridor which is also included in the open space strategy is a good initiative. However, based on the master plan, the renewal of river corridors is based on more on economic development than ecological restoration. It can serve multiple functions if the restored river corridor can be also an element in resilient infrastructure needed for addressing Jakarta's vulnerability to flooding problems and protecting biodiversity.

Another sustainability constraint is the large amount of park-and-ride provided in the transport hub plan. This is a typical of mixed-use development in Jakarta, where the area will be car-oriented with a large parking structure and usually has no integration with public transport (Adi, 2010). While future transport hubs are considered to have a high chance of solving the problem of disconnected public transports, the park and ride facilities seem to 
contradict the purpose of TOD itself. The weakness of park and ride as stated by Laconte (2011: 180) is that "Park-and-ride consumes a huge amount of urban land that could be used more efficiently". The planning should provide a detailed approach to the change expected of the people in the way they travel by restricting car usage and integrating transport hubs with pedestrian and cycling networks. Aside from reducing carbon emission, restricting car usage can also help to solve the congestion problems in Jakarta.

\section{Auckland}

Both areas in Auckland have great natural assets that are planned to be improved through various strategic approach adjacent to the "Low Carbon Strategic Action Plan" policy established by AC. The plan also aims to reduce carbon emission through strategic approach for walking and cycling, combined with the use of public transport. Auckland has problems regarding the high auto-dependency and poor patronage of PT since its networks do not cover the whole areas. Similar with Jakarta, there is no congestion pricing or other policy to reduce the car usage. However, the TOD plans have already shown the initiative restricting car usage through limited provision of park-and-ride facilities.

\section{Singapore}

Singapore managed to allocate more than $46 \%$ of its land for green surface area (Singapore Stats, 2012) through the 'pervasive green' approach, making nearly half of all urban areas green open spaces, despite its limited land area. Another strategic planning policy called 'Park Connector Network' has enabled the Singaporean government to establish a multifunctional infrastructure network which connects open spaces within the city and accommodates walking, cycling, and non-recreational functions like storm water drainage system (Chan, et al., 2011). Furthermore, there is also regulation regarding the density of trees and green buildings to complement the open space preservation.

Learning from Singapore, the government chose to switch to sustainable mobility in order to preserve liveability and reduce air pollution from private vehicles. The transit system in Singapore is designed to provide seamless connectivity through integrated and affordable public transportation, which is the same direction as Jakarta and Auckland. However, Singapore has complemented its transit system with policies that discouraged the use of private vehicles. With its policy called 'Singapore Area Licensing Scheme 1975-2000', the city-state become a pioneer in restricting car ownership, introducing congestion pricing, and encouraging the use of public transport (Laconte, 2011).

Another important aspect of Singapore's sustainability is the resilient infrastructure addressing flood problems. Singapore is a coastal city, similar with Jakarta and Auckland, and therefore has integrated the disaster risk management with its urban planning. Singapore's drainage system is a multi-function infrastructure - it also serves as parks. These parks then become the flood retention areas. Another example of this resilient infrastructure is the Marina Barrage which serves three main functions: storm water drainage system, water resource, and outdoor recreational space (Brecht, 2016). These infrastructures are the result from detail design guideline called "Active, Beautiful, Clean Waters Design Guidelines". 
Table 2 Comparative Assessment Summary

\begin{tabular}{|c|c|c|c|}
\hline Goals & $\frac{\text { Singapore (SGP) }}{\text { BENCHMARK }}$ & Jakarta (JKT) & Auckland (AKL) \\
\hline \multirow[t]{2}{*}{ Liveability: } & \multirow[t]{2}{*}{$\begin{array}{l}\text { - "Walk2Ride" } \\
\text { programme } \\
\text { - Walking and Cycling } \\
\text { Plan (WCP) for every } \\
\text { new development } \\
\text { - Public housing } \\
\text { Renewable } \\
\text { programme } \\
\text { - } 1966 \text { Land } \\
\text { Acquisition Act } \\
\text { - Design guidelines for } \\
\text { vertical housing } \\
\text { - Easy access to public } \\
\text { spaces }\end{array}$} & $\begin{array}{l}\text { - Late development of } \\
\text { pedestrian network } \\
\text { - Need detailed } \\
\text { planning for cycling } \\
\text { facilities supporting } \\
\text { pedestrian } \\
\text { - Segregated land-use } \\
\text { leads to slum } \\
\text { problems } \\
\text { - Successful civic plaza } \\
\text { in Dukuh Atas } \\
\text { Garden } \\
\text { - Land acquisition } \\
\text { causing slow } \\
\text { development } \\
\text { - Verticalization } \\
\text { constraints by } \\
\text { current culture \& } \\
\text { lifestyle preference }\end{array}$ & $\begin{array}{l}\text { - Robust planning of } \\
\text { walking and cycling } \\
\text { - Large amount of } \\
\text { existing public space } \\
\text { to be improved } \\
\text { - Dividing areas into } \\
\text { precincts according } \\
\text { to the timeline } \\
\text { - Special Housing Area } \\
\text { (SHA) } \\
\text { - Land-use is planned } \\
\text { with the right } \\
\text { amount of diversity } \\
\text { but constrains by } \\
\text { land acquisition } \\
\text { - Verticalization } \\
\text { constraints by } \\
\text { current suburban- } \\
\text { lifestyle }\end{array}$ \\
\hline & & $\begin{array}{l}\text { Recommendation: } \\
\text { - More detailed } \\
\text { planning for walking } \\
\text { and cycling } \\
\text { - Integration of land } \\
\text { ownership under the } \\
\text { government for } \\
\text { future developments } \\
\text { - Providing vertical } \\
\text { housing guidelines to } \\
\text { preserve the } \\
\text { liveability }\end{array}$ & $\begin{array}{l}\text { Recommendation: } \\
\text { - Integration of land } \\
\text { ownership under the } \\
\text { government for } \\
\text { future developments }\end{array}$ \\
\hline Affordability: & $\begin{array}{l}\text { - Public housing } \\
\text { developed by the } \\
\text { government } \\
\text { - Flexibility of housing } \\
\text { types and tenure } \\
\text { - Variations of } \\
\text { purchasing method } \\
\text { with low interest } \\
\text { - Affordable rental } \\
\text { price } \\
\text { - Quota for racial } \\
\text { diversity } \\
\text { "White sites" policy }\end{array}$ & $\begin{array}{l}\text { - Lack of housing } \\
\text { options of types and } \\
\text { tenures } \\
\text { - Low percentage of } \\
\text { affordable housing } \\
\text { development } \\
\text { - Affordable housing } \\
\text { development by } \\
\text { private developers in } \\
\text { town centre areas } \\
\text { resulted in } \\
\text { unaffordability } \\
\text { - TOD masterplans } \\
\text { need to consider the } \\
\text { long-term planning } \\
\text { outside TOD area }\end{array}$ & $\begin{array}{l}\text { - Housing development } \\
\text { planning already } \\
\text { provides housing } \\
\text { options with } \\
\text { variations of types } \\
\text { and tenures } \\
\text { - Land-use } \\
\text { accommodating long- } \\
\text { term plan } \\
\text { - Affordable housing } \\
\text { crisis due to lack of } \\
\text { land supply, private } \\
\text { land ownership \& } \\
\text { densification } \\
\text { restriction } \\
\text { - Housing } \\
\text { developments }\end{array}$ \\
\hline
\end{tabular}




\begin{tabular}{|c|c|c|c|}
\hline & & & $\begin{array}{l}\text { constraint by } \\
\text { expensive } \\
\text { construction and long } \\
\text { consenting process }\end{array}$ \\
\hline & & $\begin{array}{l}\text { Recommendation: } \\
\text { - Providing flexibility of } \\
\text { housing types and } \\
\text { tenures } \\
\text { - Consider increasing } \\
\text { the ratio for } \\
\text { affordable units } \\
\text { provided in TOD } \\
\text { housing } \\
\text { development and } \\
\text { enforce them } \\
\text { - TOD housing } \\
\text { development under } \\
\text { government } \\
\text { monitoring } \\
\text { - Providing long-term } \\
\text { planning for areas } \\
\text { affected by TOD } \\
\text { projects }\end{array}$ & $\begin{array}{l}\text { Recommendation: } \\
\text { - Allowing more high- } \\
\text { density housing } \\
\text { development near PT } \\
\text { and public amenities } \\
\text { to reduce the high } \\
\text { PIR } \\
\text { - Considering planning } \\
\text { policies to maintain } \\
\text { land values and } \\
\text { encouraging new } \\
\text { developments in } \\
\text { addition to SHA }\end{array}$ \\
\hline Susta & $\begin{array}{l}\text { - 'Pervasive green' } \\
\text { approach allocating } \\
\text { half of the area for } \\
\text { green space } \\
\text { - Green building } \\
\text { regulation } \\
\text { - Sustainable mobility } \\
\text { - Policy restricting car } \\
\text { usage and ownership } \\
\text { - Resilient and multi- } \\
\text { functional } \\
\text { infrastructure } \\
\text { integrated with } \\
\text { disaster } \\
\text { management }\end{array}$ & $\begin{array}{l}\text { - Open space strategy } \\
\text { can be optimized to } \\
\text { solve the lack of } \\
\text { green surface area } \\
\text { - Renewable river } \\
\text { corridor has } \\
\text { potential for resilient } \\
\text { infrastructure } \\
\text { addressing flood } \\
\text { problems } \\
\text { - Large amount of Park } \\
\text { and Ride facilities } \\
\text { tend to support car- } \\
\text { oriented travel mode } \\
\text { and discourage the } \\
\text { use of PT } \\
\text { - No policy to reduce } \\
\text { car usage }\end{array}$ & $\begin{array}{l}\text { - Low Carbon Strategic } \\
\text { Action Plan to } \\
\text { maintain existing } \\
\text { natural assets } \\
\text { - High auto- } \\
\text { dependency due to } \\
\text { poor patronage of PT } \\
\text { - Limiting park and ride } \\
\text { facilities (1:4 ratio) } \\
\text { - No policy to reduce } \\
\text { car usage }\end{array}$ \\
\hline
\end{tabular}




\begin{tabular}{|c|c|c|c|}
\hline & & $\begin{array}{l}\text { Recommendation: } \\
\text { - Optimization of open } \\
\text { space to encourage } \\
\text { public activities in } \\
\text { the TOD area } \\
\text { - Space allocation for } \\
\text { Park and Ride can be } \\
\text { used for other } \\
\text { facilities like multi- } \\
\text { function public open } \\
\text { spaces } \\
\text { - Considering planning } \\
\text { policies to reduce car } \\
\text { usage and } \\
\text { encouraging the use } \\
\text { of PT }\end{array}$ & $\begin{array}{l}\text { Recommendation: } \\
\text { - Improve the } \\
\text { patronage of PT } \\
\text { - Considering planning } \\
\text { policies to reduce car } \\
\text { usage in addition to } \\
\text { limited park and ride }\end{array}$ \\
\hline
\end{tabular}

\section{Conclusion}

Similar with many growing cities in the world, Jakarta and Auckland adapted the TOD strategy in facing the challenge of rapid population growth and land shortage, and the desire to build a more compact city. But the compactness is not an aim in itself - the aim is quality of life, at a reasonable price, in balance with the nature's capacity to support the urban way of life of the millions. We have termed these three goals for short - Liveability, Affordability and Sustainability (L-A-S). This paper investigated to what extent TOD strategies can achieve the L-A-S in both cities using four redevelopment areas: Dukuh Atas and Lebak Bulus in Jakarta, New Lynn and Onehunga in Auckland, as the relevant case studies.

According to the literature of TOD and compact city, the compact urban form is considered liveable, affordable and sustainable when it comprises of mix of uses within the walking distance from supporting extensive transit systems. The concept of TOD is relatively new in both cities and the outcomes are still questionable with respect to the L-A-S criteria. Drawing examples from Singapore as one of the most successful compact cities in the world, this paper offers recommendations for TOD projects in Jakarta and Auckland to achieve the L-A-S goals.

In the case of Jakarta, TOD concept policy can actually achieve the L-A-S subject to the following conditions: that the extensive transit system is complemented with robust planning of walking and cycling; land integration under the government enabling long-term planning; verticalization framed by vertical housing guidelines providing variations of types and tenures; open spaces optimised for human comfort while also creating resilient infrastructure; and the limitation of car usage to encourage the use of PT.

Likewise, in the case of Auckland, TOD concept policy can actually achieve the L-A-S subject to the following conditions: that the transit interchange is supported by extensive walking and cycling networks; integration of land ownership for long-term developments; highdensity housing and mixed-use developments; improved patronage of PT; and planning policies to reduce car usage. 
It is also clear that there are other factors influencing the success of TOD projects such as the synergy between planning policies and TOD; active public-private partnership for TOD developments; community engagement; and government support for the vision stability.

Considering the limited scope of this paper, further study is required to analyse the implementation of TOD concept policy in a bigger sample of projects if we are to assess comprehensively the L-A-S outcomes. Also, the research into case studies cannot limit itself to the analysis of master plans of projects currently under construction - future research must investigate the completed, post-occupancy outcomes too. Finally, there should be a finer level of detail on this type of research, assessing the urban design, landscape and architectural solutions at the level at which they actually touch the lives of residents.

Bearing in mind the relentless expansion of cities worldwide and the popularity of the TOD approach as a chief policy for moderating that expansion, it is fair to say that monitoring and investigating the actual L-A-S outcomes of this policy is one of the most important avenues in the $21^{\text {th }}$ century urban planning research agenda.

\section{References}

Adi, P., 2014. Next Level - Public Transport and Density Metropolitan Jakarta. Shanghai, Council on Tall Buildings and Urban Habitat.

Alexander, H. B. \& Haryanti, R., 2018. TOD Pasar Senen dan Peluang Mengembalikan Kejayaan. [Online]

Available at: https://properti.kompas.com/read/2018/12/19/231020821/tod-pasar-senendan-peluang-mengembalikan-kejayaan?page=all

[Accessed 05 2019].

Anon., 2010. New Lynn Urban Plan 2010-2030, Auckland: s.n.

Apinino, R., 2017. Mereka yang Tersingkir Karena Proyek MRT. [Online]

Available at: https://tirto.id/mereka-yang-tersingkir-karena-proyek-mrt-cyNa

Auckland Council, 2019. About the Auckland Plan 2050, s.I.: s.n.

Auckland Transport;, n.d. New Lynn Transit-Oriented Development. [Online]

Available at: https://at.govt.nz/projects-roadworks/new-lynn-transit-oriented-development/ [Accessed 05 2019].

Blakeley, R., 2015. The Planning Framework for Auckland 'Super City' an insider's view. Policy Quarterly, pp. 3-14.

Bogunovich, D., 2009. From planning sustainable cities to designing resilient urban regions. In WIT Transactions on Ecology and the Environment, Vol 120, Southampton: WIT Press.

Bogunovich, D., 2012. Urban Sustainability 2.0: Resilient Regions, Sustainable Sprawl and Green Infrastructure. In WIT Transactions on Ecology and the Environment, Vol 155, Southampton: WIT Press. Online:

https://www.witpress.com/elibrary/wit-transactions-on-ecology-and-theenvironment/155/23097 
Brecht, H., 2016. Can Singapore inspire Laos to build water-smart cities?. [Online] Available at: https://blogs.worldbank.org/water/can-singapore-inspire-laos-build-watersmart-cities

[Accessed 09 2019].

Calthorpe, P., 1993. The Next American Metropolis. Ecology, Community, and the American Dream. New York: Princeton Architectural Press.

Calthorpe, P., 2011. Urbanism in The Age of Climate Change. Washington: Island Press.

Carina, J., 2018. Warga Umum Bisa Sewa Rusunawa, Ini Syarat yang Harus Dipenuhi.... [Online]

Available at: https://megapolitan.kompas.com/read/2018/10/17/21025311/warga-umumbisa-sewa-rusunawa-ini-syarat-yang-harus-dipenuhi

[Accessed 06 2019].

Center for Liveable Clties and Urban Land Institute, 2013. 10 Principles for Liveable HighDensity Cities. Lessons from Singapore..

Chye, B., 2019. Transit-Oriented Development in Emerging Cities: Principles from Singapore. [Online]

Available at: https://www.oxfordurbanists.com/magazine/2019/3/9/transit-orienteddevelopment-in-emerging-cities-principles-from-singapore

Dittmar, H. \& Ohlan, G., 2004. The New Transit Town: Best Practices in Transit-oriented Development. Washington: Island Press.

Governor of DKI Jakarta, 2017. Governor's Regulation of DKI Jakarta Number 44: Transit Oriented Development Area, s.I.: s.n.

Hidayat, R., 2017. Proyek Rusun di Stasiun Kereta yang Panen Masalah. [Online] Available at: https://tirto.id/proyek-rusun-di-stasiun-kereta-yang-panen-masalah-cAcq [Accessed 05 2019].

ISOCARP Review 07, 2011. Liveable Cities: Urbanising World. Hague: ISOCARP.

Jabareen, R. Y., 2006. Sustainable Urban Forms. Their Typologies, Models, and Comcepts.. Journal of Planning Education and Research, pp. 38-52.

Jakarta Capital City Government, 2012. DKI Jakarta Spatial Planning 2030, s.I.: s.n.

Jakarta Capital City Government, 2012. Urban Guide Line Design, Development of MRT Jakarta, Jakarta: Jakarta Capital City Government.

Jakarta Capital City Regional Development Planning Board, 2013. Republic of Indonesia Jakarta Integrated Urban Transport Hub Development Final Report, s.I.: JAPAN INTERNATIONAL COOPERATION AGENCY (JICA).

Japan International Cooperation Agency (JICA), 2015. Preparatory Survey for Lebak Bulus Station Area Development Project in Indonesia, Jakarta: Tokyu Land Corporation.

Jha, A., 2018. "But what about Singapore?" Lessons from the best public housing program in the world. [Online]

Available at: https://blogs.worldbank.org/sustainablecities/what-about-singapore-lessonsbest-public-housing-program-world

[Accessed 06 2019]. 
JICA, 2011. Commuter Survey final report of Jabodetabek urban transport policy integration. , Jakarta: Coordinating Ministry of Economic Affairs Republic of Indonesia.

JICA, 2012. Greater Jakarta Metropolitan Priority Area (MPA). [Online] Available at: https://www.jica.go.jp/french/news/press/c8h0vm00001ner7catt/121009 01.pdf

Katz, P., 1993. The New Urbanism: Toward an Architecture of Community. New York: McGraw-Hill, Inc..

Kresna, M., 2017. Beda Nasib Penghuni Rusun Bersubsidi. [Online] Available at: https://tirto.id/beda-nasib-penghuni-rusun-bersubsidi-cfDM [Accessed 05 2019].

Le, L. X., 2016. What Vietnam can learn from Singapore about flood risk management. [Online]

Available at: https://blogs.worldbank.org/sustainablecities/what-vietnam-can-learnsingapore-about-flood-risk-management

[Accessed 06 2019].

L, M., 2013. More new apartment developments appearing. [Online]

Available at: https://www.greaterauckland.org.nz/2013/10/02/more-new-apartmentdevelopments-appearing/

[Accessed 06 2019].

L, M., 2018. The First CRL Breakthrough. [Online]

Available at: https://www.greaterauckland.org.nz/2018/12/10/the-first-crl-breakthrough/ [Accessed 06 2019].

Mariani, E., 2010. Jakarta 2030? Draft plan not looking good. [Online]

Available at: https://www.thejakartapost.com/news/2010/01/08/jakarta-2030-draft-plannot-looking-good.html

[Accessed 05 2019].

Marks, M., 2016. People Near Transit: Improving Accessibility and Rapid Transit Coverage in Large Cities. [Online]

Available at: https://www.itdp.org/

Newman, P. \& Kenworthy, J., 1999. Sustainability and Cities: Overcoming Automobile Dependence. Washington: Island Press.

OECD, 2012. Compact City Policies. A comparative Assessment. OECD Green Growth Studies. s.l.:OECD Publishing.

Ollivier, G. \& Djalal, D., 2017. Transit-oriented development and the case of the Marina Bay area in Singapore. [Online]

Available at: https://blogs.worldbank.org/eastasiapacific/transit-oriented-development-andcase-marina-bay-area-singapore

[Accessed 06 2019].

Panuku Development Auckland, 2017. Auckland: s.n.

PDW Architects, 2019. Laporan Final Dek Pejalan Kaki Dukuh Atas, Jakarta: PDW Architects. 
PT MRT Jakarta, 2017. Achieving The Milestones. Annual Report 2017, Jakarta: PT MRT Jakarta.

Rodrigues, A., 2018. Transit Oriented Developments and some of the underlying factors influencing them. [Online]

Available at: https://www.greaterauckland.org.nz/2018/07/10/transit-orienteddevelopments-and-some-of-the-underlying-factors-influencing-them/

[Accessed 05 2019].

Singapore Housing and Development Board ;, n.d. Public Housing - A Singapore Icon. [Online]

Available at: https://www.hdb.gov.sg/cs/infoweb/about-us/our-role/public-housing--asingapore-icon

[Accessed 06 2019].

SOM, n.d. MRT JAKARTA TRANSIT-ORIENTED DEVELOPMENT MASTER PLAN. [Online] Available at: https://www.som.com/projects/mrt jakarta transit-

oriented development master plan

[Accessed 05 2019].

Thomas, R. et al., 2018. Is transit-oriented development (TOD) an internationally transferable policy concept?. Regional Studies, Volume 52, pp. 1201-1213.

TOTALINDO; n.d. TRANSIT ORIENTED DEVELOPMENT (TOD) LEBAK BULUS - JAKARTA SELATAN. [Online]

Available at: http://totalindo.co.id/portfolio-items/transit-oriented-development-tod-lebakbulus-jakarta-selatan/

[Accessed 06 2019].

W, Budiati et al, 2018. Determining the potential for Transit Oriented Development along the MRT Jakarta corridor. IOP Conference Series: Earth and Environmental Science.

Wang, X., 2018. Livability to start with the neighborhood-Singapore's stories (Part 2/2). [Online]

Available at: https://blogs.worldbank.org/sustainablecities/livability-start-neighborhoodsingapore-stories-part-2

[Accessed 06 2019].

Wang, X., 2018. Livability to start with the neighborhood - Singapore's urban practice (Part 1/2). [Online]

Available at: https://blogs.worldbank.org/sustainablecities/livability-start-neighborhoodsingapore-urban-practice-part-1

[Accessed 06 2019].

Widhana, D. H., 2016. Balada Korban Penggusuran yang Tinggal di Rusun. [Online] Available at: https://tirto.id/balada-korban-penggusuran-yang-tinggal-di-rusun-ccoQ

Widhana, D. H., 2016. Balada Korban Penggusuran yang Tinggal di Rusun. [Online] Available at: https://tirto.id/balada-korban-penggusuran-yang-tinggal-di-rusun-ccoQ

Widhana, D. H., 2016. Penghuni Rusun: "Harapan Saya Punah". [Online] Available at: https://tirto.id/penghuni-rusun-harapan-saya-punah-ccoU 
Wijaya, C. A., 2018. Expert urges Jakarta to focus on adding more green spaces. [Online] Available at: https://www.thejakartapost.com/news/2018/03/08/expert-urges-jakarta-tofocus-on-adding-more-green-spaces.html [Accessed 05 2019]. 